\title{
VERIFICATION OF VENTSAR XL - A SPREADSHEET VERSION OF VENTSAR
}

\author{
Ad2
}

A. A. Simpkins ort' 28 the

OSTI

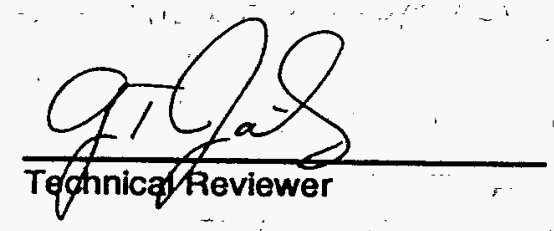

May 1996

Westinghouse Savannah River Company Savannah River Site Alken, SC 29808

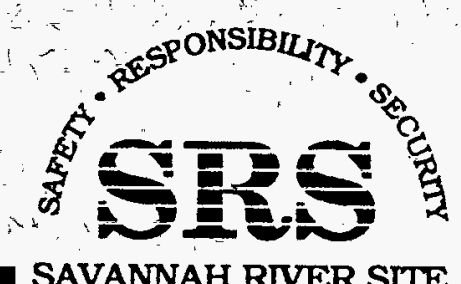

PREPARED FOR THE U.S. DEPARTMENT OF ENERGY UNDEA CONTRACT NO. DE-AC09-89SR18035 


\section{DISCLAIMER}

This report was prepared as an account of work sponsored by an agency of the United States Government. Neither the United States Government nor any agency thereof, nor any of their employees, makes any warranty, express or implied, or assumes any legal liability or responsibility for the accuracy, completeness, or usefulness of any information, apparatus, product, or process disclosed, or represents that its use would not infringe privately owned rights. Reference herein to any specific commercial product, process, or service by trade name, trademark, manufacturer, or otherwise does not necessarily constitute or imply its endorsement, recommendation, or favoring by the United States Government or any agency thereof. The views and opinions of authors expressed herein do not necessarily state or reflect those of the United States Government or any agency thereof.

This report has been reproduced directly from the best available copy.

Available to DOE and DOE contractors from the Office of Scientific and Technical Information, P.O. Box 62, Oak Ridge, TN 37831; prices available from (615) 576-8401.

Available to the public from the National Technical Information Service, U.S. Department of Commerce, 5285 Port Royal Road, Springfield, VA 22161. 


\section{DISCLAIMER}

Portions of this document may be illegible in electronic image products. Images are produced from the best available original document. 


\title{
VERIFICATION OF VENTSAR XL - A SPREADSHEET VERSION OF VENTSAR
}

\author{
A. A. Simpkins
}

Issued: May 1996 
VENTSAR is a computer model that analyzes flow patterns of pollutants on or near buildings. Plume rise may be considered. VENTSAR has been modified to allow for execution on a Macintosh using Microsoft Excel. This new version is called VENTSAR XL. All methodologies are identical to those within VENTSAR. This report provides verification of all models within VENTSAR XL. Strict comparisons were made with VENTSAR to ensure consistency between the two models. 


\section{TABLE OF CONTENTS}

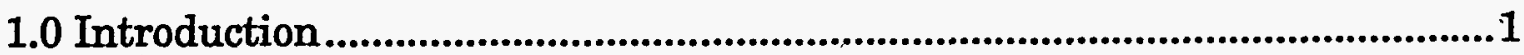

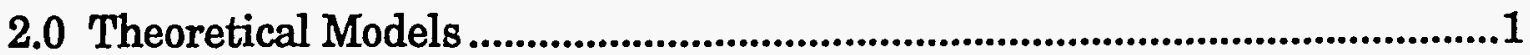

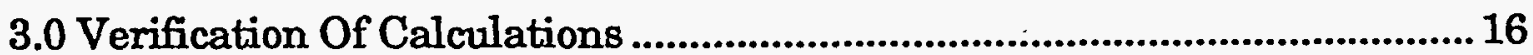

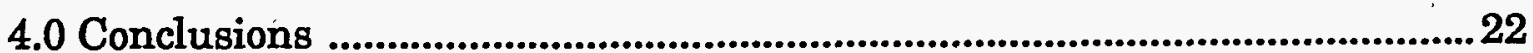

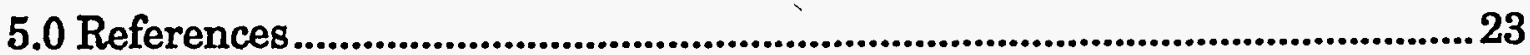

Appendix A. Original Test Case Demonstration ................................................25

Appendix B Additional Test Case Demonstration ..............................................40

Appendix C. Hand Calculations ........................................................................44 


\section{LIST OF TABLES}

Table 1. Wind Speed Category Ranges ..................................................................3

Table 2. Classification of Atmospheric Stability ................................................3

Table 3. Brigg's Vertical Diffusion Coefficient Formulas ..................................5

Table 4. Comparison of VENTSAR and VENTSAR XL for Test Case 2 .........17

Table 5. Input parameters for Plume Rise Verification.................................... 18

Table 6. Hand Calculations for Plume Rise Verification ................................. 18

Table 7. Input parameters for Building Wake Effects Verification ................ 19

Table 8. Hand Calculations for Building Wake Effects Verification...............20

Table 9. Input parameters for Building Wake Effects and PR Verification........................................................................................21

Table 10. Hand Calculations for Building Wake Effects and PR

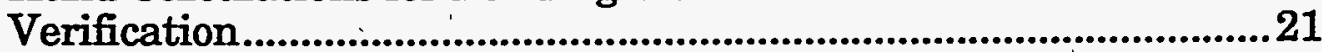

Table A1. VENTSAR Test Cases................................................................27

Table A2. Results for Test Case 1 (Releàse Height =50 m) ..........................28

Table A3. Results for Test Case 1 (Release Height =55 m) ............................33

Table A4. Test Căses 3 through 8 ....................................................................38

Table B1. Test Cases Parameters ..........................................................................41

Table B2. Comparison of VENTSAR XL and VENTSAR ...............................42

\section{LIST OF FIGURES}

Figure 1. Recirculation Zones for Building Wake Effects Calculations....... 11

Figure 2. Dimensions of Building and Penthouse used with VENTSAR XL

Figure 3. Concentration locations for Building Wake Effects Verification 


\title{
VERIFICATION OF VENTSAR XL - A SPREADSHEET VERSION OF VENTSAR
}

\author{
A. A. Simpkins \\ Westinghouse Savannah River Company \\ Savannah River Technology Center \\ Aiken, SC 29808
}

\subsection{INTRODUCTION}

The VENTSAR code is an upgraded and improved version of the VENTX code (Smith and Weber 1983), which estimates contaminant concentrations on or near a building from a release at a nearby location. The code calculates the concentrations for a given meteorological exceedance probability or for a given stability and wind speed combination. A single building can be modeled and a penthouse can be added to the top of the building. Plume rise also may be considered. Contaminant release types can be chemical or radioactive. Downwind concentrations are determined at user-specified incremental distances.

VENTSAR resides on the IBM Mainframe at SRS. For ease in calculations, VENTSAR methodologies were transferred to a Microsoft Excel Spreadsheet. The new version is entitled VENTSAR XL. Use of a spreadsheet model will allow for immediate display of output as well as ease in input preparation.

\subsection{THEORETICAL MODELS}

This section discusses the theoretical models and data files that are employed within VENTSAR XL. For a complete set of user instructions refer to Simpkins (1996). The only difference between VENTSAR and VENTSAR XI is the removal of the additional vent height increment option. These calculations can be accomplished by executing the spreadsheet for each of the requested vent heights. This feature typically was not used.

\subsection{Gaussian Plume Model}

The pollutant dispersion calculations in the VENTSAR XL code are based on a reflecting Gaussian plume model (Hanna 1982). Along the plume centerline, the dispersion factor or relative air concentration, defined as the ratio of the pollutant concentration $\chi\left(\mathrm{kg} / \mathrm{m}^{3}\right.$ or $\left.\mathrm{Ci} / \mathrm{m}^{3}\right)$ to the source strength $\mathrm{Q}(\mathrm{kg} / \mathrm{sec}$ or $\mathrm{Ci} / \mathrm{sec})$, is given by the equation: 


$$
\frac{\chi}{Q}=\frac{1}{2 \pi \sigma_{y} \sigma_{z} U_{S}}\left[e^{-\left(\frac{\left(z-h_{z}\right)^{2}}{2 \sigma_{z}^{2}}\right)}+e^{-\left(\frac{\left(z+h_{z}\right)^{2}}{2 \sigma_{s}^{2}}\right)}\right]
$$

where:

$\chi / Q \quad$ the dispersion factor $\left(\mathrm{sec} / \mathrm{m}^{3}\right)$

$z \quad$ height above the ground surface (m)

he effective release height (m)

$U_{S} \quad$ wind speed at the release height, $(\mathrm{m} / \mathrm{sec})$

oy the standard deviation of the concentration distribution in the horizontal cross-plume direction (m)

$\sigma_{z}$ the standard deviation of the concentration distribution in the vertical direction $(\mathrm{m})$

Annual averaged values of $\chi / Q$ are calculated as:

$$
\operatorname{annual}(\overline{\chi / Q})=\sum_{i, j}^{6.7} P_{i j}\left(\frac{\chi}{Q}\right)_{i j}
$$

where:

i wind speed category

j stability class

$(X / Q)_{i} \quad$ relative air concentration for meteorological condition $(i, j)$

$P_{i} \quad$ the probability of a particular meteorological condition ( $\left.i, j\right)$ occurring within a five-year time period

\subsubsection{Meteorological Data Files}

Meteorological data files for use with VENTSAR XI exist for the following areas onsite: A, C, D, F, H, K, L; and P. The meteorological data are obtained from hourly averages of measurements made at 1.5 seconds intervals. The files contain joint frequency distributions and reciprocal average wind velocities categorized by wind direction, speed, and stability class. Reciprocal average wind speeds are utilized since air concentration is 
inversely proportional to wind speed. Table 1 provides wind speed category definitions. Validation of the meteorological data are the responsibility of the Environmental Transport Group. See Parker (1992) and Weber (1993) for more details on the wind statistics obtained from the SRS area meteorological towers. VENTSAR XI accesses meteorological data for the period of 19871991. The quality assurance of this data is handled by the Environmental Transport Group.

Table 1. Wind Speed Category Ranges

\begin{tabular}{|c|c|}
\hline $\begin{array}{c}\text { Speed } \\
\text { Category }\end{array}$ & $\begin{array}{c}\text { Range } \\
\text { (m/sec) }\end{array}$ \\
\hline 1 & $0<U \leq 2$ \\
2 & $2<U \leq 4$ \\
3 & $4<U \leq 6$ \\
4 & $6<U \leq 8$ \\
5 & $8<U \leq 12$ \\
6 & $U \geq 12$ \\
\hline
\end{tabular}

Atmospheric stability is classified by standard deviations of the lateral or azimuthal wind direction. Area meteorological towers contain

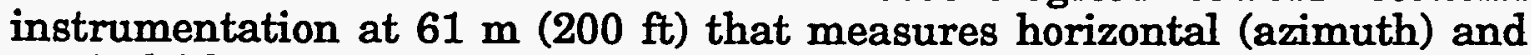
vertical (elevation) wind directions. Also, direct measurements of turbulence, expressed as standard deviations of fluctuations about mean azimuth (noted either as $\sigma_{a}$ or $\left.\sigma_{\theta}\right)$ and elevation $\left(\sigma_{e}\right)$ angles, are made at $61 \mathrm{~m}$.

For calculational purposes within the spreadsheet, an assumed average value of $\sigma_{\theta}$ is chosen for the atmospheric stability class of interest. Ranges for $\sigma_{\theta}$ and the values that are used within VENTSAR XI are shown in Table 2.

Table 2. Classification of Atmospheric Stability

\begin{tabular}{|c|c|c|}
\hline $\begin{array}{c}\text { Pasquill } \\
\text { Category }\end{array}$ & $\begin{array}{c}\text { Range for } \sigma_{\theta} \\
\text { (degrees) }\end{array}$ & $\begin{array}{c}\sigma_{\theta} \text { Used in } \\
\text { VENTSAR XL } \\
\text { (degrees) }\end{array}$ \\
\hline A & $23 \leq \sigma_{\theta}$ & 27.5 \\
B & $18 \leq \sigma_{\theta}<23$ & 22.5 \\
C & $13 \leq \sigma_{\theta}<18$ & 17.5 \\
D & $8 \leq \sigma_{\theta}<13$ & 12.5 \\
E & $4 \leq \sigma_{\theta}<8$ & 7.5 \\
F & $2 \leq \sigma_{\theta}<4$ & 3.75 \\
G & $\sigma_{\theta}<2$ & 2.00 \\
\hline
\end{tabular}




\subsubsection{Pasquill-Briggs Dispersion Coefficients}

The lateral and vertical dispersion coefficients within VENTSAR XL are those derived by Pasquill (1976) and Briggs (1973), respectively. The equation representing Pasquill's lateral dispersion coefficients is

$$
\sigma_{y}=\sigma_{\theta} X f(X)
$$

where:

$\sigma_{\theta} \quad$ standard deviation of lateral wind direction (radians) [See Table 2]

$X \quad$ downwind distance (km)

$f(X)$. function of distance, $X(\mathrm{~km})$, as discussed below

Pasquill developed formulations for $f(X)$ with a table of values for distances less than $10 \mathrm{~km}$ and the following equation for distances greater than $10 \mathrm{~km}$ :

$$
f(X)=0.33\left[\frac{10}{X}\right]^{0.5}
$$

For distances less than $10 \mathrm{~km}$, the following equation was derived from the table of values with $X$ in kilometers:

$$
f(X)=\frac{1}{1+0.031(1000 X)^{0.46}}
$$

Pasquill (1976) gives a detailed description on how the coefficients were developed using data from experiments at various sites.

The vertical diffusion coefficients defined by Briggs (1973) and then refined by Briggs and published in Hanna (1982) for open-country conditions are represented in Table 3 as a function of Pasquill's atmospheric stability classes. For these equations the units of $X$ should be meters.

\subsection{Plume Rise}

Plume rise models are based on fundamental laws of fluid mechanics, conservation of mass, potential density, and momentum. The quantities across the plume are referred to as "top-hat" meaning that discontinuities in temperature, speed and etc. are assumed at the plume boundary. Therefore, for the models employed here, constant values are assumed inside the plume, and another set of constant values is assumed outside of the plume. VENTSAR XL considers plume rise due to both buoyancy and momentum effects. 
Table 3. Brigg's Vertical Diffusion Coefficient Formulas

\begin{tabular}{|c|l|}
\hline $\begin{array}{c}\text { Pasquill Stability } \\
\text { Category }\end{array}$ & \multicolumn{1}{|c|}{$\sigma_{\mathrm{z}}(\mathrm{X}$ in meters $)$} \\
\hline A & $0.20 X$ \\
B & $0.12 X$ \\
C & $0.08 X(1+0.0002 X)^{-0.5}$ \\
D & $0.06 X(1+0.0015 X)^{-0.5}$ \\
E & $0.03 X(1+0.0003 X)^{-1}$ \\
F & $0.02 X(1+0.0003 X)^{-1}$ \\
G & $0.01 X(1+0.0003 X)^{-1}$ \\
\hline
\end{tabular}

Several different mechanisms can increase or decrease the height of the plume at downwind distances. Plume rise due to momentum and buoyancy effects can increase the height of the plume while downwash can decrease the height of the plume. The effective plume height at a given distance, $X$, downwind is

$$
h(X)=h_{s}-\Delta h_{D}+\Delta h_{B}(X)+\Delta h_{M}(X)
$$

where:

$h_{s} \quad$ initial height of the source

$\Delta h_{D} \quad$ source height change due to downwash

$\Delta h_{B} \quad$ source height change due to buoyancy effects

$\Delta h_{M} \quad$ source height change due to momentum effects

\subsubsection{Downwash}

Downwash occurs when the plume is drawn downward due to low pressure in the wake of the stack. Downwash will not occur if the velocity of the effluent $\left(V_{e},\right)$ is a significantly greater than the wind speed $(U)$. Downwash is generally recognized to occur when $V_{e} / U$ is less than 1.5 (Briggs 1973). When the ratio is less than 1.5 the following equation is applied to determine the effects of downwash (Hanna 1982):

$$
\Delta \mathrm{h}_{\mathrm{D}}=2\left(\frac{\mathrm{V}_{\mathrm{e}}}{\mathrm{U}}-1.5\right) \mathrm{D}
$$

where 
$D \quad$ the internal stack diameter (m)

$V_{e} \quad$ effluent velocity $(\mathrm{m} / \mathrm{s})$

$U$ crosswind velocity $(\mathrm{m} / \mathrm{s})$

-Recent work by Snyder (1991) suggests that downwash seldom has consequences due to the fact that conditions are typically associated with small diameters, and the change in stack height due to downwash is only of a few diameters. Snyder states that "serious downwash will occur only for sources with: $V_{\mathrm{e}} \mathrm{D}<0.5(60,000)\left(0.15 \mathrm{~cm}^{2} \mathrm{~s}^{-1}\right) \sim 0.5 \mathrm{~m}^{2} \mathrm{~s}-1 . "$

\subsubsection{Buoyancy Effects}

For most plumes the primary contributor to rise is buoyancy, which results from density differences between the effluent and the atmosphere (Briggs 1984). The initial buoyancy flux for a plume is determined by (Hanna 1982):

$F_{o}=g(D R H O)(C M S)$

where:

Fo buoyancy flux $\left(\mathrm{m}^{4} / \mathrm{s}^{3}\right)$

g acceleration due to gravity $\left(9.8 \mathrm{~m} / \mathrm{s}^{2}\right)$

CMS volume flux at the stack exit $\left(\mathrm{m}^{3} / \mathrm{s}\right)$

DRHO density ratio (unitless), defined below

Plumes are considered dense when the density ratio, $D R H O$, is greater than zero (Meroney 1982a). DRHO is determined using the following equation:

$D R H O=\frac{M W_{a} T_{e}-M W_{e} T_{a}}{2 M W_{a} T_{e}}$

where:

$M W_{e} \quad$ molecular weight of the effluent

$M W_{a} \quad$ molecular weight of the air (28.9)

$T_{e} \quad$ temperature of effluent (K) .

$T_{a} \quad$ temperature of air (K) 
The Froude number $(F r)$ is used to represent the ratio of inertial forces to buoyancy forces (Snyder 1972). If DRHO $\leq 0$, the plume is lighter than air and the Froude number is not determined. The plume falls to the ground close to the source when the Froude number is less than 7.7 (Meroney 1982a). The Froude number is calculated as follows:

$$
F r=\frac{U}{\sqrt{g * D R H O * D}}
$$

where:

Fr Froude number (unitless)

$U \quad$ wind speed $(\mathrm{m} / \mathrm{s})$

D plume exit diameter (m)

For the vertical motion of the plume, the environmental stability parameter, $S$, plays an important role for unstable conditions. The stability parameter is set to unity for all classes except $E, F$ and $G$ where

$$
S=\frac{g * \frac{\partial T_{2}}{\partial z}}{T_{z}}
$$

where:

$S \quad$ stability parameter $\left(\mathrm{s}^{-2}\right)$

$\frac{\partial T_{a}}{\partial z}=0.02$ for $\mathrm{E}, 0.03$ for $\mathrm{F}$, and $0.04^{\circ} \mathrm{C} / 100 \mathrm{~m}$ for G stability (Hanna 1982).

Now that many of the initializing parameters have been determined, the increase in plume height due to buoyancy can be calculated. For unstable to neutral conditions buoyancy is limited to a distance XSTR from the source using the following formulations (Briggs 1969):

For $F_{o}>55 \mathrm{~m}^{4} / \mathrm{s}^{3}$

$$
X S T R=120.7 F_{0}^{0.4}(m)
$$

For $F_{o} \leq 55 \mathrm{~m}^{4} / \mathrm{s}^{3}$

$$
X S T R=49.0 F_{0}^{0.025}(m)
$$


Using the above determined distances, the increase in plume height due to buoyancy effects for unstable to neutral conditions where $X<X S T R$ is determined using the following equation (Briggs 1969):

$$
\Delta h_{B}=1.6 \frac{F_{0}^{1 / 3} X^{2 / 3}}{U}
$$

For distances greater than XSTR for unstable to neutral conditions, the same equation is used, except $X$ is set to a constant value of XSTR.

For stability classes $\mathrm{E}, \mathrm{F}$ and $\mathrm{G}$ with calm winds (given below) the increase in plume height is determined by the following (Briggs 1969):

$$
\Delta h_{B}=5.0\left[\frac{F_{o}}{S^{3 / 2}}\right]^{1 / 4}
$$

For stability classes $\mathrm{E}, \mathrm{F}$ and $\mathrm{G}$ with the wind speed greater than the calm wind speed, and for distances greater than or equal to $X T S T=2.07 U / S P$ buoyancy is less dominating and the increase in plume height is given by the following (Hanna 1982):

$$
\Delta h_{B}=2.6\left[\frac{F_{o}}{(U) S}\right]^{1 / 3}
$$

For distances less than XSTR, Equation 14 is applied.

By setting equations 15 and 16 equal and solving for $U$, calm winds are given by the following relationship:

$$
U<0.141^{*}\left(F_{o} * S^{1 / 2}\right) 0.25 \mathrm{~m} / \mathrm{s}
$$

\subsubsection{Momentum Effects}

Plume rise may also occur because the initial vertical velocity of the effluent is great enough to elevate the plume. Plume rise due to momentum effects near the source for unstable to neutral weather conditions (Stability Classes A-D) is determined by the following equation (Briggs 1976):

$$
\Delta h_{M}=\left[\frac{3 \pi}{4 \beta^{2}}\right]^{1 / 3}\left[\frac{D W_{e} M_{o}}{U}\right]^{2 / 3} X^{1 / 3}
$$

where:

$\beta \quad=0.4+1.2 U / V_{e}$, (unitless), 
$U \quad$ wind speed $(\mathrm{m} / \mathrm{s})$

$V_{e} \quad$ effluent velocity $(\mathrm{m} / \mathrm{s})$

D diameter of the stack (m)

$M_{0}$ measure of relative density of effluent plume to that of air:

$$
M_{0}=\left[\frac{M W_{a} T_{a}}{M W_{a} T_{a}}\right]^{1 / 2}
$$

$X$ downwind distance (m)

For ease in calculation within the spreadsheet the equation is rewritten as

$$
\Delta h_{M}=\left[B 1 * X * D H M O M^{2}\right]^{2 / 3}
$$

where

$$
\begin{aligned}
& B 1=\frac{0.75 * \pi}{\left(0.4+1.2 U / V_{c}\right)^{2}} \\
& D H M O M=D * \frac{V_{c}}{U} M_{o}
\end{aligned}
$$

with all terms previously defined.

The above equation is applicable for all distances less than XTEST where

$$
X T E S T=\frac{27.0 D H M O M}{B 1}
$$

For distances where $X \geq X T E S T$ the increase in plume height due to momentum effects is given by the following equation (Briggs 1969):

$$
\Delta h_{M}=3 D H M O M
$$

For stable weather conditions (Stability Classes E, F, and G) the change in plume height due to momentum effects is equal to the minimum of the following two equations (Briggs 1969): 


$$
\begin{aligned}
\Delta h_{M} & =4.0 \sqrt{\frac{D H M O M * U}{2 S^{1 / 2}}} \\
\Delta h_{M} & =1.5\left(\frac{D H M O M^{2} U}{4 S^{1 / 2}}\right)^{1 / 3}
\end{aligned}
$$

\subsection{Building Wake Effects}

An exact mathematical solution to the plume interaction with air flow does not exist. However, a great deal of useful quantitative information has been obtained using wind-tunnel simulations of flow around model buildings, and a limited number of measurements. around full-scale buildings of relatively simple geometry. Semi-empirical models consolidating these simulations and experiments are available for estimating pollutant concentrations around buildings. A summary of the methods available for determining flow patterns and pollutant concentrations near buildings with a simple block-like structure has been prepared by Hanna (1982).

Wind passing over and around buildings creates a complicated dispersion pattern. A recirculation cavity and zones of high turbulence are created on the building roof with a roof cavity region produced downwind of the structure. These regions may trap effluent material and produce high ground- or roof-level concentrations. Models that neglect turbulence effects near structures will usually underestimate pollutant concentrations on building roofs or near buildings. Since air-intake vents may be located on building roofs or near the ground downwind of a release source, an estimation of pollutant concentrations on or near a structure is important in determining expected pollutant. levels. Therefore, a methodology was adapted to determine the effect of plume interaction with the air-flow pattern around buildings. This provides a useful tool for determining heights of new stacks so that acceptable pollutant levels near the source and downwind buildings can be assured.

Figure 1 (Wilson 1979) shows a cross-section of the flow over a building with the wind perpendicular to the face of the building. The recirculation cavity (Zone I) is created due to the separation of the flow from the upwind edge of the roof. The flow recirculates and the turbulence levels are very high. Only if the roof is long enough will the flow reattach to the roof. The boundary of the high turbulence region (Zone II) is not precisely defined. Turbulence generated in the shear layers at the edge of the recirculation cavity result in accelerated diffusion to the roof level of any gases. Zone II is defined such that it also includes Zone I. The roof wake region (Zone III) is depicted in Figure 1 in an exaggerated form. This region's boundary is essentially straight and parallel with the flow. Gases that are released in this region will have some downwash and more rapid spreading than the gases above Zone III. Zone III also includes Zones I and II. 
Analytical models have been associated with the regions discussed previously. Building effects are included in the model using the techniques presented by Wilson (1979). 'The dimensions of recirculation zones, high turbulence zones, and wake cavities associated with the building and any penthouse structure are determined based on building dimensions. If the plume is not over the building or the downwind wake cavity, the height above the ground, $z$, is set equal to zero to give ground-level concentrations.

Figure 1. Recirculation Zones for Building Wake Effects Calculations

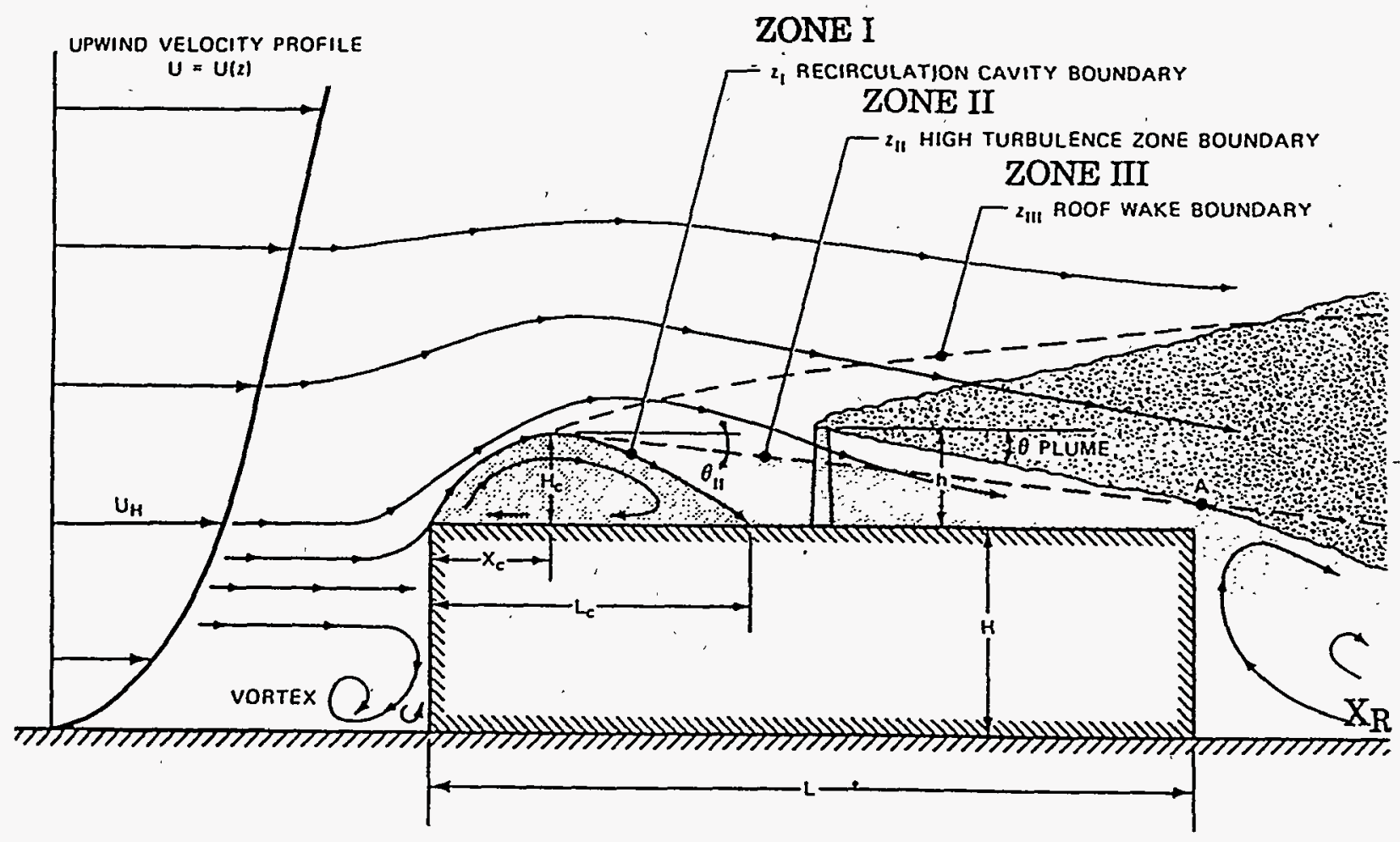


Various fluid modeling experiments have led to the development of models to predict the behavior of wind flow around buildings. The dimensional parameters describing the building of interest in VENTSAR XI are shown in Figure 2. These dimensions are consistent with the wind being perpendicular to the building face. When ratios of $\mathrm{L} / \mathrm{H}$ (where $\mathrm{L}$ and $\mathrm{H}$ correspond to the length and height of the building or penthouse) are greater than one, reattachment of streamlines to the roof and sides is expected. This however, may not be the case if $\mathrm{W} / \mathrm{H}$ is very large. The length the recirculation cavity zone (Zone I) extends from the upwind edge of the building is given by the following expression:

$L_{c} \approx 0.9 R$

where:

$R \approx\left(B_{\min }\right)^{2 / 3}\left(B_{\max }\right)^{1 / 3}$

where $B_{\min }$ is the smaller of $H$ or $W$ and $B_{\max }$ is the larger. The length of the cavity zone should be calculated for both the building and penthouse separately and then summed. All building dimension units are in meters.

Figure 2. Dimensions of Building and Penthouse used with VENTSAR XI

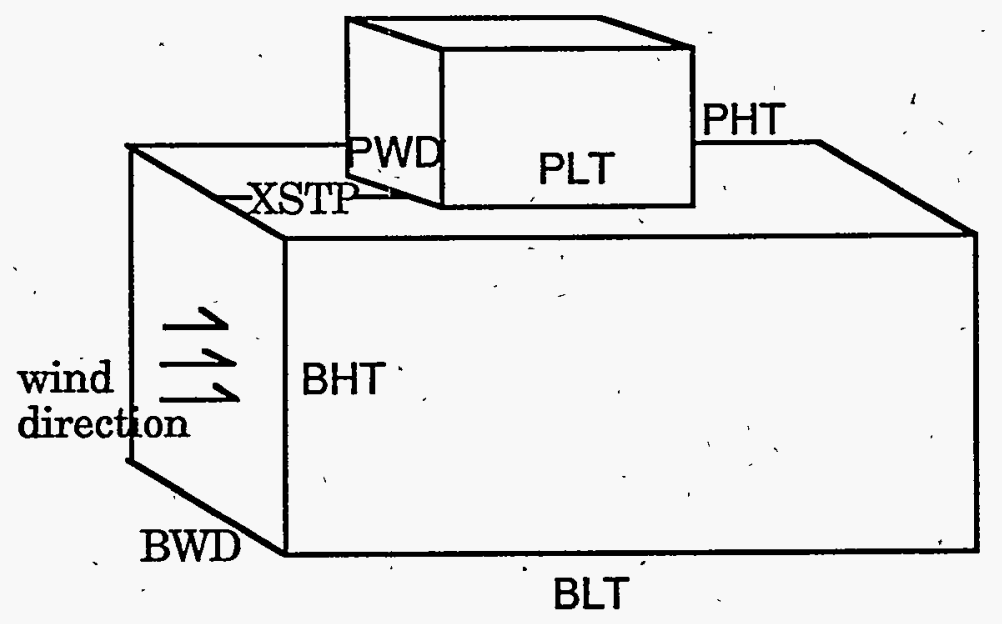

The maximum height of the recirculation zone (Zone I) is

$H_{c} \approx 0.22 R$

and is assumed to occur at a distance of $R / 2$ from the edge of the building. The length of the cavity zone- is defined for both the building and the penthouse. 
The distance beyond the building where plumes may be caught and mixed to the ground is called the wake cavity. The empirical formula for the length of the wake cavity is (Hanna 1982):

$$
X_{r}=\frac{A * W}{1+B(W / H)}
$$

where

W the building width,

$H$ the building height, and

$A$ and $B$ are discussed below.

Separate values for $A$ and $B$ are used depending on whether the flow reattaches to the roof and sides of the building. Cases of reattachment occur when $\mathrm{L} / \mathrm{H} \geq 1$. For this case

$A=1.75$

$B=0.25$

For cases where the flow does not reattach to the building

$$
\begin{aligned}
& A=-2.0+0.37\left(\frac{L}{H}\right)^{1 / 3} \\
& B=-0.15+0.305\left(\frac{L}{H}\right)^{1 / 3}
\end{aligned}
$$

When the recirculation cavity does not reattach to the building roof, calculation of the effective release height is altered. Following Briggs, if the adjusted release height $h^{\prime}$ is less than the building height $H$, then the adjusted effective height is given by (Briggs 1973):

$h_{\text {eff }}=h^{\prime}-1.5 B_{\min }$

where

$h_{\text {eff }}$ the effective plume,

$h^{\prime} \quad$ the release height adjusted by downwash and plume rise, and 
$B_{\min }$ the smaller of the width or height of the building.

If the emission height at the building is such that $H<h^{\prime}<H+1.5 B_{\min }$, then the adjusted effective release height is:

$h_{\text {eff }}=2 h^{\prime}-\left(H+1.5 B_{\min }\right)$

If $h^{\prime} \geq H+1.5 B_{\min }$, the plume is out of the wake of the building and no effects from the building are seen, therefore, $h_{\text {eff }}=h^{\prime}$.

When there is a change in elevation on the building roof, three separate flow regimes must be considered. Let $X_{s}$ be the distance from the leading edge of the building to the step change in roof elevation. $R_{u}$ and $R_{s}$ are the scaling lengths given by Equation 28 for the building and penthouse upwind faces, respectively. The following three flow regimes can occur:

(i) $X_{s}<0.5\left(R_{u}+R_{s}\right)$. The leading edge of the building is connected in a straight line to the top of the penthouse to form a recirculation cavity. Roof cavity heights and turbulence zone boundaries are calculated. using $R=\left(R_{\mathrm{u}}+R_{\mathrm{S}}\right)$;

(ii) $0.5\left(R_{u}+R_{s}\right)<X_{s}<2\left(R_{u}+R_{s}\right)$. The recirculation cavity height $\mathrm{H}_{\mathrm{c}}$ and location $\mathrm{X}_{\mathrm{c}}$ on the upwind portion of the roof are calculated using $\mathrm{R}=$ $R_{\mathrm{u}}+R_{\mathrm{s}}$. The top of this cavity region is joined in a straight line with the top of the penthouse to form a high turbulence zone. The cavity height on the penthouse roof and the downwind high turbulence zone boundary are then calculated using $R_{\mathrm{S}}$ as a scale length; or

(iii) $X_{s}>2\left(R_{u}+R_{s}\right)$. The upwind roof and penthouse roof are treated as. two separate buildings with scaling lengths $R_{u}$ and $R_{S}$, respectively.

Using the $R$ values determined above for a given point, the height of cavity Zone $I$ is determined (Wilson 1979).

For downwind distances less than $0.5 \mathrm{R}$ :

$$
Z=0.28 R\left(\frac{X}{R}\right)^{1 / 3}
$$

where

$\mathrm{R}$ determined above based on building dimensions, and

$\mathrm{X}$ downwind distance. 
For downwind distance $\mathrm{X}$ where $0.5 \mathrm{R}<\mathrm{X}<\mathrm{L}$ :

$Z=0.27 R-0.1 X$

For use within the code, the value of $\mathrm{Z}$ calculated above is added to the height of the building to determine the relative air concentration. Beyond the building $\mathrm{Z}=0$.

When building wake effects are considered, adjustments must be made to the relative air concentration equation. Some fraction (f) of the effluent plume will be entrained into the wake cavity. For the model used in VENTSAR XI, this fraction is estimated as the ratio of $X / Q$ evaluated at the top of the cavity when it first forms to the value of $X / Q$ at the plume centerline. The material trapped within the wake cavity behaves as if it originates from an area source of building dimensions. Meroney (1982b) has shown that a simple expression useful for estimating pollutant concentrations within the cavity is:

$$
\left(\frac{\chi}{Q}\right)_{\text {avv }}=\frac{\mathrm{f}}{\mathrm{HWU}_{\mathrm{s}}}
$$

Equation 39 assumes that the effluent rapidly mixes in a uniform volume within the cavity. Turbulence within the wake cavity will produce a relatively constant pollutant concentration within this region. Experimental evidence indicates that this assumption will give conservative predictions of ground-level concentrations in most cases.

For distances beyond the wake cavity, surface $X / Q$ values will contain a component from the elevated plume $(\chi / Q)_{\mathrm{E}}$ (see Eq. 1) and from the area source of material trapped within the cavity $(X / Q)_{T}$. Following Hosker (1984), this is expressed as:

$$
\frac{\chi}{Q}=(1-f)\left(\frac{\chi}{Q}\right)_{E}+f\left(\frac{\chi}{Q}\right)_{T}
$$

Meroney (1982b) proposed an empirical expression for $(\mathcal{X} / \mathrm{Q})_{\mathrm{T}}$ as:

$$
\left(\frac{\chi}{Q}\right)_{T}=\left(\frac{\chi}{Q}\right)_{0} \exp \left[-0.5\left(\frac{\chi}{Q}\right)_{0} \pi H W U_{s}\left(\frac{h}{H}\right)^{2}\right]
$$

where the centerline ground-level plume concentration is

$$
\left(\frac{\chi}{Q}\right)_{0}=\frac{1}{U_{.}\left(\pi \sigma_{y} \sigma_{z}+0.5 H W\right)}
$$


In Equation 42, $\sigma_{\mathrm{y}}$ and $\sigma_{\mathrm{z}}$ are evaluated using Pasquill and Briggs formulations with $x$ equal to the distance from the start of the wake cavity. Initial values for $\sigma_{\mathrm{y}}$ and $\sigma_{\mathrm{z}}$ in Equation 42 are taken to be the minimum building cross-sectional dimensions.

\subsection{VERIFICATION OF CALCULATIONS}

Strict comparisons were made between VENTSAR and VENTSAR XL to ensure proper application of methodologies within the spreadsheet model. First, each of the test cases previously used for VENTSAR were duplicated using VENTSAR XL. Input for each of the test cases is shown in Appendix A. An additional set of four test cases were executed using VENTSAR XL and the results were compared with results from VENTSAR. These additional test cases are shown in Appendix B. Hand calculations also were performed to demonstrate certain aspects of the code.

\subsection{Comparison with Original Test Cases}

Results from VENTSAR XL are compared with results from VENTSAR test cases. VENTSAR had a default number of increments set at 200. Results are shown here for a select number of points. Positions were chosen in relation to building structure. If a smaller number of increments are used results may not be identical beyond the end of the building. The results may differ because the fraction of the plume that is trapped in the building wake cavity is determined at the point just beyond the building and this fraction is used within the remainder of the cavity zone (See Section 3.3).

In Appendix A, the results for test case 1 are shown in their entirety for the first two release heights. This test case was chosen for a complete comparison because it exercises both the plume rise and building wake effects methodologies.

Looking closely at Appendix A, differences are less than $1 \%$ for all distances except $505.0 \mathrm{~m}$ downwind which is $5.61 \%$ different for the first release height. This difference can be explained due to the difference in division in FORTRAN and Excel Macros. The minimum and maximum distance of interest was $10 \mathrm{~m}$ and $1000 \mathrm{~m}$, respectively, for test case one. With 200 increments the $x$ increment $(\Delta x)$ is equal to $(1000-10) / 200$ which equals 4.95 . With VENTSAR on the IBM Mainframe, FORTRAN determined this value to be 4.949999. Therefore, at increments number 100, VENTSAR and VENTSAR XI determine the distance as follows: 


\section{VENTSAR}

$\mathrm{D}=\min +$ No. increments $* \mathrm{x}$

$\mathrm{D}=10+100 * 4.949999$

$\mathrm{D}=504.9999 \mathrm{~m}$

$$
\begin{aligned}
& \text { VENTSAR XI, } \\
& D=\min +\text { No. increments } * \mathrm{x} \\
& \mathrm{D}=10+100 * 4.95 \\
& \mathrm{D}=505.0 \mathrm{~m}
\end{aligned}
$$

While this difference may seem inconsequential, it is used to determine whether or not D is still on top of the building. Within VENTSAR on the IBM Mainframe, $D<505.0$ and therefore is on top of the building. In VENTSAR $\mathrm{XL}, \mathrm{D}$ is not less than $\mathbf{5 0 5 . 0}$ and therefore is past the building. As a result different values of $z$ are used by VENTSAR and VENTSAR XI for this particular point and thus different answers. For all test cases, this was the only instance that this difference occurred.

Table 4 shows the results of the comparison between VENTSAR and VENTSAR XL for test case number two at several downwind distances. Both the annual average air concentration and the $99.5 \%$ air concentration are shown.

Table 4. Comparison of VENTSAR and VENTSAR XL for Test Case 2

\begin{tabular}{|c|c|c|c|c|c|c|}
\hline $\begin{array}{c}\text { Downwind } \\
\text { Distance } \\
(\mathrm{m})\end{array}$ & $\begin{array}{c}\text { VENTSAR } \\
99.5 \% \chi / \mathrm{Q} \\
\left(\mathrm{s} / \mathrm{m}^{* * 3)}\right.\end{array}$ & $\begin{array}{c}\text { VENTSAR } \\
\text { Annual } \chi / \mathrm{Q} \\
\left(\mathrm{s} / \mathrm{m}^{* * 3}\right)\end{array}$ & $\begin{array}{c}\text { VENTSAR XY } \\
99.5 \% \chi / \mathrm{Q} \\
\left(\mathrm{s} / \mathrm{m}^{* * 3)}\right.\end{array}$ & $\begin{array}{c}\text { VENTSAR XY } \\
\text { Annual } \chi / \mathrm{Q} \\
\left(\mathrm{s} / \mathrm{m}^{* * 3}\right)\end{array}$ & $\begin{array}{c}\% \text { Diff } \\
99.5 \% \chi / \mathrm{Q} \\
(\%)\end{array}$ & $\begin{array}{c}\% \text { Diff } \\
\text { Annual } \chi / \mathrm{Q} \\
(\%)\end{array}$ \\
\hline 10 & $0.00 \mathrm{E}+00$ & $0.00 \mathrm{E}+00$ & $0.00 \mathrm{E}+00$ & $0.00 \mathrm{E}+00$ & $0.00 \%$ & $0.00 \%$ \\
109 & $9.40 \mathrm{E}-41$ & $7.85 \mathrm{E}-32$ & $9.34 \mathrm{E}-41$ & $7.82 \mathrm{E}-32$ & $0.69 \%$ & $0.41 \%$ \\
208 & $4.39 \mathrm{E}-20$ & $1.34 \mathrm{E}-17$ & $4.37 \mathrm{E}-20$ & $1.34 \mathrm{E}-17$ & $0.40 \%$ & $-0.03 \%$ \\
307 & $1.01 \mathrm{E}-12$ & $1.07 \mathrm{E}-13$ & $1.01 \mathrm{E}-12$ & $1.07 \mathrm{E}-13$ & $-0.11 \%$ & $0.35 \%$ \\
406 & $5.59 \mathrm{E}-10$ & $4.00 \mathrm{E}-12$ & $5.59 \mathrm{E}-10$ & $4.00 \mathrm{E}-12$ & $-0.07 \%$ & $0.10 \%$ \\
505 & $9.46 \mathrm{E}-09$ & $3.98 \mathrm{E}-11$ & $9.43 \mathrm{E}-09$ & $3.98 \mathrm{E}-11$ & $-0.01 \%$ & $-0.06 \%$ \\
604 & $4.01 \mathrm{E}-08$ & $1.53 \mathrm{E}-10$ & $4.01 \mathrm{E}-08$ & $1.53 \mathrm{E}-10$ & $-0.03 \%$ & $0.05 \%$ \\
703 & $8.99 \mathrm{E}-08$ & $3.45 \mathrm{E}-10$ & $8.99 \mathrm{E}-08$ & $3.45 \mathrm{E}-10$ & $0.05 \%$ & $0.11 \%$ \\
802 & $1.45 \mathrm{E}-07$ & $5.99 \mathrm{E}-10$ & $1.45 \mathrm{E}-07$ & $5.99 \mathrm{E}-10$ & $0.34 \%$ & $-0.03 \%$ \\
901 & $1.93 \mathrm{E}-07$ & $9.11 \mathrm{E}-10$ & $1.93 \mathrm{E}-07$ & $9.11 \mathrm{E}-10$ & $-0.11 \%$ & $0.01 \%$ \\
\hline
\end{tabular}

The' results for the remaining test cases are shown in Appendix A. Differences were less than $1 \%$ for all distances. If a specific stability class and wind speed was selected then only the $x / Q$ corresponding to the particular combination is shown because no annual average is calculated.

\subsection{Comparison with Additional Test Cases}

Four additional test cases were developed to test various aspects of the spreadsheet. The input for these test cases is shown in Appendix B. The results of the comparison also are shown in Appendix B. Differences were less than $0.01 \%$ for all distances. 


\subsection{Plume Rise Hand Calculations}

Table 5 shows the input parameters that were used in the spreadsheet to verify the plume rise module. Variables were chosen at random within the ranges of validity. Table 6 shows a comparison of hand calculations and VENTSAR XL results for several downwind distances. Differences are less' than 1\% for all distances shown. See Appendix C Section 1 for the actual hand calculations.

Table 5. Input parameters for Plume Rise Verification.

\begin{tabular}{|l|l|}
\hline Parameter & Input \\
\hline Area or Release Location & A \\
Building Height & $0.0 \mathrm{~m}$ \\
Building Width & $0.0 \mathrm{~m}$ \\
Building Length & $0.0 \mathrm{~m}$ \\
Penthouse Height & $0.0 \mathrm{~m}$ \\
Penthouse Width & $0.0 \mathrm{~m}$ \\
Penthouse Length & $0.0 \mathrm{~m}$ \\
Penthouse Distance & $0.0 \mathrm{~m}$ \\
Minimum Distance of Interest & $10 \mathrm{~m}$ \\
Maximum Distance of Interest & $1010 \mathrm{~m}$ \\
Number of Increments & 100 \\
Compass Sector of Building Location & 3 \\
Distance of Vent from Roof Edge & 0.0 \\
Vent Height & $20.0 \mathrm{~m}$ \\
Radioactive Calculation? & No \\
Release Rate & 0 \\
Mole Fraction of Pollutant & $1.8 \mathrm{E}-03$ \\
Vent Gas Flow Rate & $50 \mathrm{~m} / \mathrm{s}$ \\
Averaging Option & $\mathrm{No}$ \\
Wind Speed & $6 \mathrm{~m} / \mathrm{s}$ \\
Stability Class & $4(\mathrm{D})$ \\
Vent Diameter & $1.0 \mathrm{~m}$ \\
Vent Gas Molecular Weight & 78.12 \\
Vent Gas Air Temperature & $40 \mathrm{C}$ \\
Air Temperature & $20 \mathrm{C}$ \\
\hline
\end{tabular}

Table 6. Hand Calculations for Plume Rise Verification

\begin{tabular}{|c|c|c|c|}
\hline $\begin{array}{l}\text { Downwind } \\
\text { Distance (m) }\end{array}$ & $\begin{array}{l}\text { Relative Air } \\
\text { Concentration }\left(\mathrm{s} / \mathrm{m}^{3}\right) \\
\text { VENTSAR XL }\end{array}$ & $\begin{array}{l}\text { Relative Air } \\
\text { Concentration (s/m } \\
\text { Hand Calculations }\end{array}$ & $\begin{array}{l}\text { Percent } \\
\text { Difference }\end{array}$ \\
\hline 10 & $0.00 \mathrm{E}+00$ & $0.00 \mathrm{E}+00$ & $0.0 \%$ \\
200 & $8.16 \mathrm{E}-17$ & $8.22 \mathrm{E}-17$ & $-0.7 \%$ \\
1000 & $4.40 \mathrm{E}-07$ & $4.41 \mathrm{E}-07$ & $-0.2 \%$ \\
\hline
\end{tabular}




\subsection{Building Wake Effects Verification}

Table 7 shows the input parameters that were used to verify the building wake effects module. Figure 3 shows a side view of the building and the places at which calculations were performed to verify the concentrations. These locations were selected to ensure all zones were considered. Table 8 shows the results of the comparison. Differences are less than $1 \%$. See Appendix A, Section 2 for the hand calculations.

Table 7. Input parameters for Building Wake Effects Verification

\begin{tabular}{|l|l|}
\hline Parameter & Input \\
\hline Area or Release Location & $\mathrm{K}$ \\
Building Height & $10.0 \mathrm{~m}$ \\
Building Width & $20.0 \mathrm{~m}$ \\
Building Length & $30.0 \mathrm{~m}$ \\
Penthouse Height & $5.0 \mathrm{~m}$ \\
Penthouse Width & $10.0 \mathrm{~m}$ \\
Penthouse Length & $10.0 \mathrm{~m}$ \\
Penthouse Distance & $10.0 \mathrm{~m}$ \\
Minimum Distance of Interest & $10 \mathrm{~m}$ \\
Maximum Distance of Interest & $50 \mathrm{~m}$ \\
Number of Increments & 8 \\
Compass Sector of Building Location & 3 \\
Distance of Vent from Roof Edge & -10.0 \\
Vent Height & $20.0 \mathrm{~m}$ \\
Radioactive Calculation? & Yes \\
Release Rate & $1 \mathrm{Ci} / \mathrm{min}$ \\
Mole Fraction of Pollutant & 0 \\
Vent Gas Flow Rate & 0 \\
Averaging Option & No \\
Wind Speed & $6 \mathrm{~m} / \mathrm{s}$ \\
Stability Class & $4(\mathrm{D})$ \\
Vent Diameter & $0.1 \mathrm{~m}$ \\
Vent Gas Molecular Weight & 78.12 \\
Vent Gas Temperature & 0 \\
Ambient Air Temperature & 0 \\
\hline
\end{tabular}


Figure 3. Concentration locations for Building Wake Effects Verification

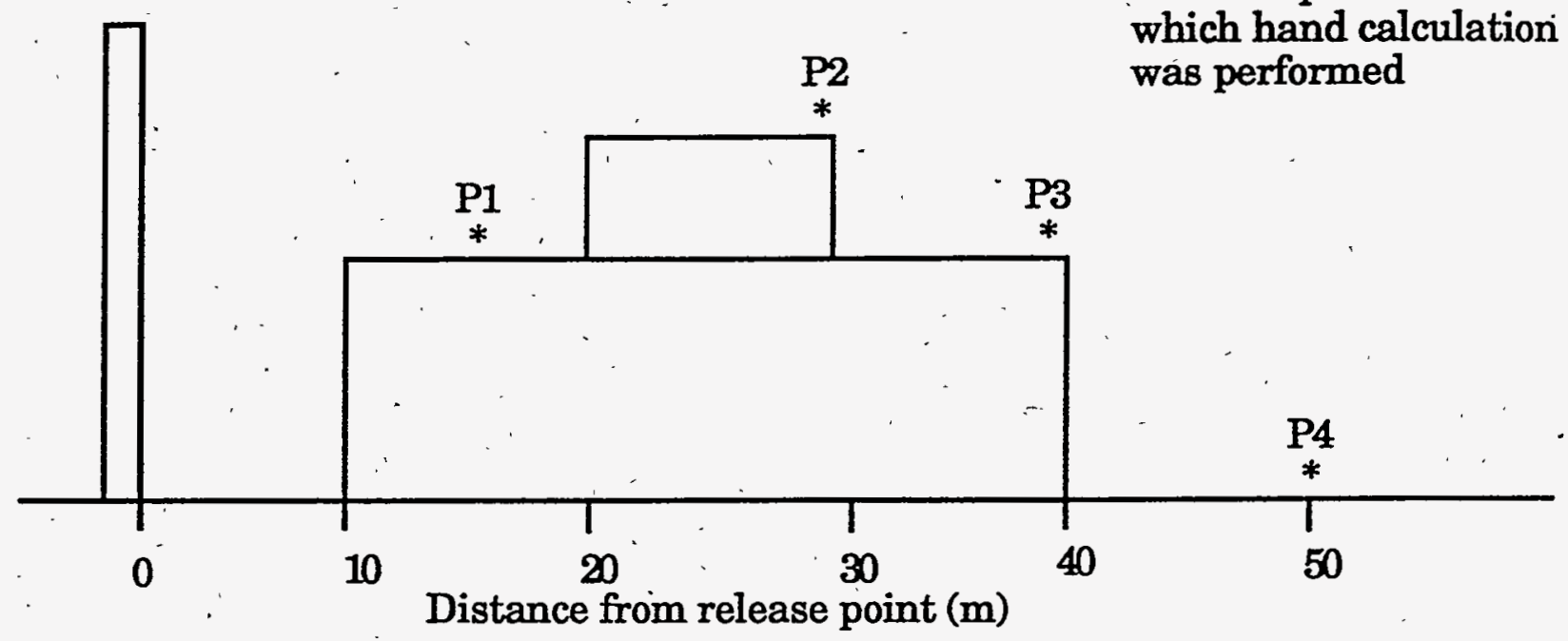

Table 8. Hand Calculations for Building Wake Effects Verification

\begin{tabular}{|l|c|c|c|}
\hline $\begin{array}{l}\text { Downwind } \\
\text { Distance (m) } \\
\text { (Position) }\end{array}$ & $\begin{array}{l}\text { Relative Air } \\
\text { Concentration }\left(\mathrm{s} / \mathrm{m}^{3}\right) \\
\text { VENTSAR XL }\end{array}$ & $\begin{array}{l}\text { Relative Air } \\
\text { Concentration }\left(\mathrm{s} / \mathrm{m}^{3}\right)\end{array}$ & $\begin{array}{c}\text { Percent } \\
\text { Difference } \\
\text { Hand Calculations }\end{array}$ \\
\hline 15 (P1) & $1.13 \mathrm{E}-14$ & $1.13 \mathrm{E}-14$ & $0.0 \%$ \\
30 (P2) & $4.69 \mathrm{E}-05$ & $4.68 \mathrm{E}-05$ & $0.2 \%$ \\
40 (P3) & $3.16 \mathrm{E}-19$ & $3.16 \mathrm{E}-19$ & $0.0 \%$ \\
50 (P4) & $8.42 \mathrm{E}-14$ & $8.36 \mathrm{E}-14$ & $0.7 \%$ \\
\hline
\end{tabular}

\subsection{Verification of Plume Rise and Building Options Combined}

A case with both a simple building and plume rise was analyzed. The input parameters for this comparison are shown in Table 9. The results of the hand calculations compared with the actual code output are shown in Table 10. The differences were $2 \%$ or less for all of the positions selected. These differences are due to rounding. When the results are large negative exponents slight differences in the exponents can result in magnified differences in the results. See Appendix C, Section 3 for an example of the hand calculations. 
Table 9. Input parameters for Building Wake Effects and PR Verification

\begin{tabular}{|l|l|}
\hline Parameter & Input \\
\hline Area or Release Location & $\mathrm{A}$ \\
Building Height & $10.0 \mathrm{~m}$ \\
Building Width & $20.0 \mathrm{~m}$ \\
Building Length & $30.0 \mathrm{~m}$ \\
Penthouse Height & $0.0 \mathrm{~m}$ \\
Penthouse Width & $0.0 \mathrm{~m}$ \\
Penthouse Length & $0.0 \mathrm{~m}$ \\
Penthouse Distance & $0.0 \mathrm{~m}$ \\
Minimum Distance of Interest & $10 \mathrm{~m}$ \\
Maximum Distance of Interest & $1010 \mathrm{~m}$ \\
Number of Increments & 200 \\
Compass Sector of Building Location & 3 \\
Distance of Vent from Roof Edge & -10.0 \\
Vent Height & $0.0 \mathrm{~m}$ \\
Radioactive Calculation? & Yes \\
Release Rate & $1 \mathrm{Ci} / \mathrm{min}$ \\
Mole Fraction of Pollutant & 0 \\
Vent Gas Flow Rate & 50 \\
Averaging Option & $\mathrm{No}$ \\
Wind Speed & $4 \mathrm{~m} / \mathrm{s}$ \\
Stability Class & $3(\mathrm{C})$ \\
Vent Diameter & $1 \mathrm{~m}$ \\
Vent Gas Molecular Weight & 78.12 \\
Vent Gas Temperature & $40 \mathrm{C}$ \\
Ambient Air Temperature & $20 \mathrm{C}$ \\
\hline
\end{tabular}

Table 10. Hand Calculations for Building Wake Effects and PR Verification

\begin{tabular}{|c|c|c|c|}
\hline $\begin{array}{l}\text { Downwind } \\
\text { Distance }(\mathrm{m})\end{array}$ & $\begin{array}{l}\text { Relative Air } \\
\text { Concentration }\left(\mathrm{s} / \mathrm{m}^{3}\right) \\
\text { VENTSAR XL }\end{array}$ & $\begin{array}{l}\text { Relative Air } \\
\text { Concentration (s/m } \\
\text { Hand Calculations }\end{array}$ & $\begin{array}{c}\text { Percent } \\
\text { Difference }\end{array}$ \\
\hline 30 & $7.78 \mathrm{E}-73$ & $7.66 \mathrm{E}-73$ & $1.5 \%$ \\
45 & $9.60 \mathrm{E}-69$ & $9.51 \mathrm{E}-69$ & $1.0 \%$ \\
100 & $9.82 \mathrm{E}-23$ & $9.70 \mathrm{E}-23$ & $1.2 \%$ \\
500 & $1.89 \mathrm{E}-07$ & $1.88 \mathrm{E}-07$ & $0.5 \%$ \\
\hline
\end{tabular}




\subsection{CONCLUSIONS}

VENTSAR XL has been verified and is operating as expected. Comparisons with VENTSAR and hand calculations demonstrate that the spreadsheet is utilizing the same methods as VENTSAR. Use of the spreadsheet version will allow for ease in input preparation and immediate display of output. 


\subsection{REFERENCES}

Briggs, G.A., 1969: Plume Rise, Air Resources Atmospheric Turbulence and Diffusion Laboratory, TID-25075, USAEC; Division of Technical Information.

Briggs, G.A., 1973: "Diffusion Estimation for Small Emissions", in Environmental Research Laboratory, Air Resources Atmospheric Turbulence and Diffusion Laboratory, Annual Report, ATDL-106, USDOC-NOAA.

Briggs, G.A., 1976: "Plume Rise Predictions", Lectures on Air Pollution and Environmental Impact Analyses, American Meteorological Society, Boston, Mass.

Briggs, G.A., 1984: "Plume Rise and Buoyancy Effects", Atmospheric Science and Power Production, DOE/TIC-27601, p 327.

Hanna, S. R., 1982: and G. A. Briggs, and R. P. Hosker, Jr., Handbook on Atmospheric Diffusion. DOE/TIC-11223 (DE82002045) Technical Information Center, USDOE.

Hosker, R.P., 1984: "Flow and Diffusion Near Obstacles", Atmospheric Science and Power Production, DOE/TIC-27601, p 241.

Meroney, R.N., 1982a: "Wind-Tunnel Experiments on Dense Gas Dispersion. Journal of Hazardous Materials", Journal of Hazardous Materials 6, p 85.

Meroney, R.N., 1982b: Engineering Meteorology, E.J. Plate, Editor, Elsevier Scientific Publishing Company, New York.

Parker, M.J., 1992: The 1987-1991 Savannah River Site Meteorological Data Base(U), USDOE Report WSRC-RP-92-598, Westinghouse Savannah River Company, Aiken, SC.

Pasquill, F., 1961: "The Estimation of the Dispersion of Windborne Material", Meteorological Magazine 90, p 33.

Pasquill, F., 1976: Atmospheric Dispersion Parameters in Gaussian Plume Modeling: Part II. Possible Requirements for Change in the Turner Workbook Values, EPA Report EPA-600/4-76306, US Environmental Protection Agency.

Simpkins, A.A. 1996: VENTSAR XL User's Manual, USDOE Report WSRCRP-96-229, Westinghouse Savannah River Company, Aiken, SC. 
Smith, F.G. and A.H.'Weber 1983: A Computer Code for the Estimation of Pollutant Concentrations on or Near Buildings, National Technical Information Service, DP-1668, Springfield, VA.

Snyder, W.H. 1972: "Similarity Criteria for the Application of Fluid Models to the Study of Air Pollution Meteorology", Boundary-Layer Meteorology 3, D. Reidel Publishing Company, Dordrecht-Holland, $\mathrm{p}$ 113.

Snyder, W.H. 1991: "Fluid Modeling Simulation of Stack-Tip Downwash for Neutrally Buoyant Plumes", Atmospheric Environment, Volume 25A, No $12, \mathrm{p} 2937$.

Weber, A.H., 1993: Comparison of Savannah River Site's Meteorological Databases(U), USDOE Report .WSRC-RP-93-269, Westinghouse Savannah River Company, Aiken, SC.

Wilson, D.J., 1979: "Flow Patterns Over Flat-Roofed Buildings and Application to Exhaust Stack Design", ASHRAE Transactions 85, Part $2, \mathrm{p} 284$. 


\section{APPENDIX A. ORIGINAL TEST CASE DEMONSTRATION}




\section{APPENDIX A. ORIGINAL TEST CASE DEMONSTRATION}

Each of the VENTSAR Test cases were executed using VENTSAR XI to ensure that all MACROS had been coded properly. Table A1 shows the input parameters used for each of the test cases.

Tables A2 and A3 show the results of the comparison for test case 1 for the first two release heights respectively. The results are shown in their entirety. Percentage differences between VENTSAR and VENTSAR XL are also shown. Table A4 shows the results of the remaining test cases for a selected number of user distances. All numbers were compared but only the selected distances are shown here. 


\begin{tabular}{|c|c|c|c|c|c|c|c|c|}
\hline Parameter & Case 1 & Case 2 & Case 3 & Case 4 & Case 5 & Case 6 & Case 7 & CASE 8 \\
\hline Consider Plume Rise\$ & YES & YES & NO & YES & NO & NO & YES & NO \\
\hline Area of Release & $\mathbf{P}$ & D & $\mathrm{H}$ & C & $A$ & $\mathrm{~K}$ & $F$ & OTHER\# \\
\hline Bullding Helght & 10 & 0 & 5 & 20 & 15 & 8 & 10 & 12 \\
\hline Bullding Width & 20 & 0 & 30 & 100 & 200 & 200 & 10 & 30 \\
\hline Building Length & 30 & 0 & 100 & 30 & 200 & 10 & 10 & 15 \\
\hline Penthouse Hoight & 1 & 0 & 3 & 6 & 7 & 3 & 5 & 6 \\
\hline Penthouse Width & 2 & 0 & 5 & 10 & 200 & 150 & 5 & 20 \\
\hline Penthouse Length & 3 & 0 & 5 & 10 & 100 & 8 & 5 & 10 \\
\hline Bldg. to Ponthouse & 5 & 0 & 20 & 0 & 100 & 2 & 0 & 1 \\
\hline Min. Vent to Receptor & 10 & 10 & 10 & 10 & 10 & 10 & 10 & 10 \\
\hline Max. Vent to Receptor & 1000 & 1000 & 1000 & 1000 & 1000 & 1000 & 1000 & 1000 \\
\hline Compass Sector & NNW & $\mathbf{S}$ & $\mathbf{N}$ & NE & WNW & SSE & BE & E \\
\hline Vent to Roof Edge & -500 & 0 & .100 & 10 & -10 & 500 & 100 & -30 \\
\hline Vent Height & 50 & 25 & 5 & 0 & 100 & 50 & 5 & 0 \\
\hline Radioactive Release? & NO & NO & YES & NO & YES & YES & NO & YES \\
\hline Rlease Rate (CV/min) & - $\quad$ & $\cdot \quad-$ & 1 & - & 1 & 1 & - & 1 \\
\hline Pollutant Mole Fraction & 0.000001 & 0.000001 & - & 0.000001 & - & - & 0.000001 & - \\
\hline Vent-Gas Flow Rate $\left(m^{\wedge} 3 / \mathrm{s}\right)$ & 500 & 750 & 1000 & 100 & 500 & 750 & 1000 & 100 \\
\hline Met. Averaging? & YES & YES & NO & NO & NO & YES & YES & NO \\
\hline Probability Lovol & 0.005 & 0.005 & $\cdot$ & - & - & 0.005 & 0.005 & - \\
\hline Wind Speod $(\mathrm{m} / \mathrm{s})$ & - & - & 2 & 1 & 4 & - & 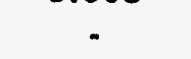 & 3 \\
\hline Stability Class. & - & - & D & $\mathbf{F}$ & B & - & - & A. \\
\hline Vent Dlameter & 3 & 2 & 3 & 1 & 3 & 2 & 2 & 1 \\
\hline Vent-Gas Molecular Woight & 210 & 200 & 200 & 190 & 200 & 180 & 230 & 220 \\
\hline Vent-Gas Temp(C) & 20 & 17 & 17 & 18 & 17 & 17 & 19 & 14 \\
\hline Amblent Alr Temp(C) & 15 & 17 & 17 & 12 & 17 & 17 & 16 & 13 \\
\hline Vent Helght Increment & 5 & 0 & 0 & 1 & 5 & 0 & 0 & 5 \\
\hline
\end{tabular}

$\$$ plume rise only for chemical release (with pollutant mole fraction)

\# Release Coordinates at center of site: E58000; N 62000 
Table A2. Results for Test Case 1 (Release Height $=50 \mathrm{~m}$ )

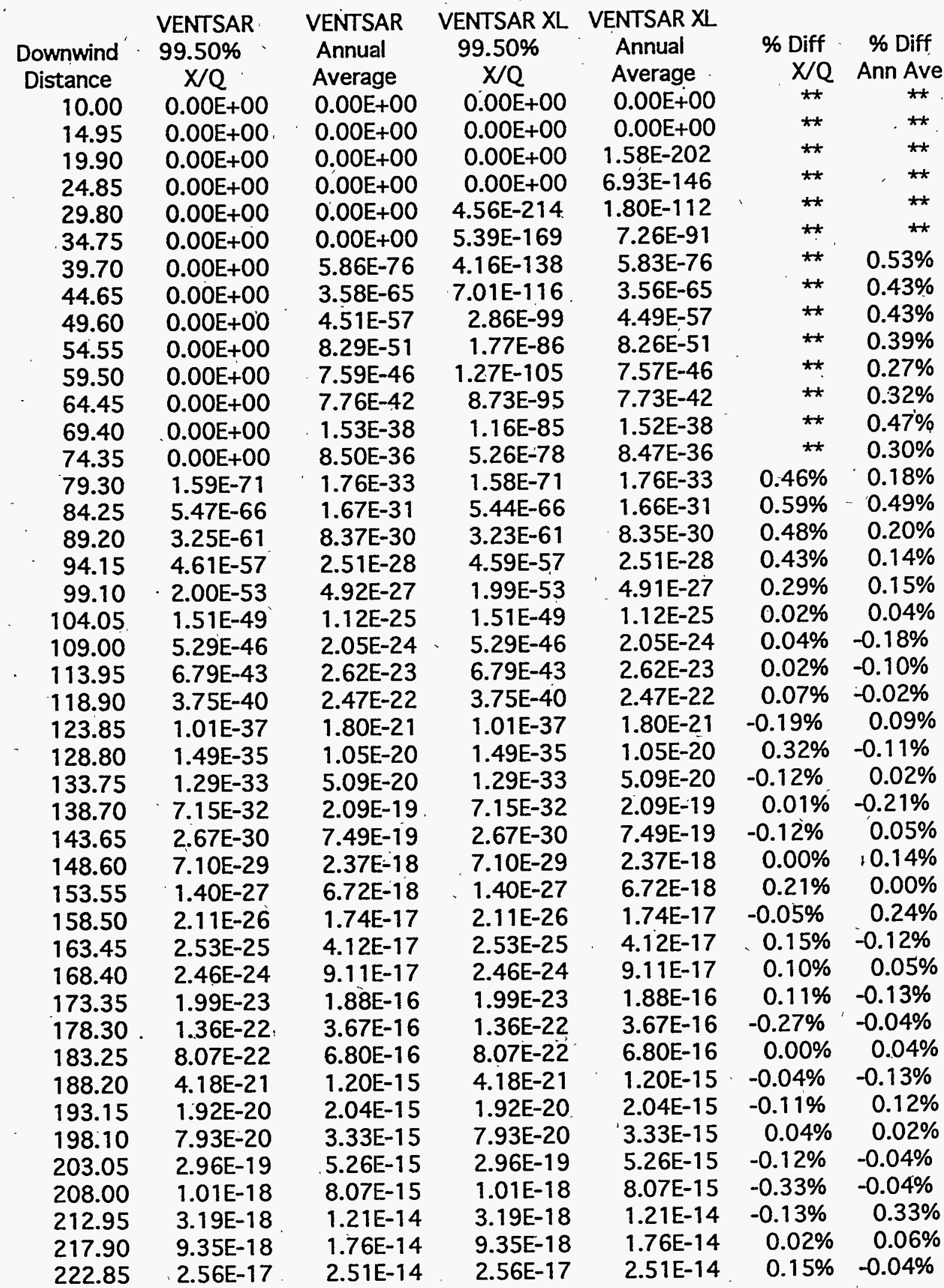

** Value in VENTSAR Printed as zero since below cutoff. 


\begin{tabular}{|c|c|c|c|c|c|c|}
\hline 227.80 & $6.57 \mathrm{E}-17$ & $3.52 E-14$ & $6.57 \mathrm{E}-17$ & $3.52 E-14$ & $0.04 \%$ & $0.11 \%$ \\
\hline 232.75 & $1.59 E-16$ & $4.84 E-14$ & 1.59E-16 & $4.84 E-14$ & $-0.23 \%$ & $0.03 \%$ \\
\hline 237.70 & $3.67 E-16$ & $6.55 E-1.4$ & $3.67 E-16$ & $6.55 E-14$ & $0.04 \%$ & $-0.08 \%$ \\
\hline 242.65 & 8.05E-16 & 8.75E-14 & $8.05 E-16$ & $8.75 E-14$ & $0.05 \%$ & $-0.05 \%$ \\
\hline 247.60 & $1.69 E-15$ & $1.15 \mathrm{E}-13$ & $1.69 E-15$ & $1.15 \mathrm{E}-13$ & $0.17 \%$ & $-0.36 \%$ \\
\hline 252.55 & 3.39E-15 & $1.50 E-13$ & $3.39 E-15$ & $1.50 E-13$ & $-0.13 \%$ & $-0.23 \%$ \\
\hline 257.50 & $6.57 E-15$ & $1.94 \mathrm{E}-13$ & $6.57 E-15$ & $1.94 E-13$ & $-0.03 \%$ & $0.14 \%$ \\
\hline 262.45 & $1.23 E-14$ & 2.47E-13 & $1.23 E-14$ & 2.47E-13 & $0.17 \%$ & $-0.05 \%$ \\
\hline 267.40 & $2.22 E-14$ & $3.12 \mathrm{E}-13$ & 2.22E-14 & $3.12 E-13$ & $0.02 \%$ & $-0.08 \%$ \\
\hline 272.35 & $3.89 E-14$ & $3.91 E-13$ & $3.89 E-14$ & $3.91 E-13$ & $-0.01 \%$ & $-0.02 \%$ \\
\hline 277.30 & $6.63 \mathrm{E}-14$ & $4.86 \mathrm{E}-13$ & $6.63 E-14$ & $4.86 E-13$ & $0.05 \%$ & $0.06 \%$ \\
\hline 282.25 & $1.10 \mathrm{E}-13$ & $5.98 E-13$ & $1.10 \mathrm{E}-13$ & - $5.98 \mathrm{E}-13$ & $0.10 \%$ & $-0.08 \%$ \\
\hline 287.20 & $1.78 E-13$ & 7.32E-13 & 1.78E-13 & $7.32 E-13$ & $0.14 \%$ & $0.02 \%$ \\
\hline 292.15 & $2.81 E-13$ & 8.89E-13 & $2.81 \mathrm{E}-13$ & 8.89E-13 & $0.05 \%$ & $0.05 \%$ \\
\hline 297.10 & 4.34E-13 & $1.07 E-12$ & $4.34 E-13$ & $1.07 E-12$ & $-0.05 \%$ & $-0.12 \%$ \\
\hline 302.05 & $6.58 \mathrm{E}-13$ & $1.28 E-12$ & $6.58 \mathrm{E}-13$ & $1.28 \mathrm{E}-12$ & $0.04 \%$ & $-0.24 \%$ \\
\hline 307.00 & 9.77E-13 & $1.53 E-12$ & 9.77E-13 & $1.53 E-12$ & $-0.03 \%$ & $0.20 \%$ \\
\hline 311.95 & $4.58 E-15$ & $1.81 \mathrm{E}-12$ & $4.58 E-15$ & $1.81 E-12$ & $0.07 \%$ & $0.22 \%$ \\
\hline 316.90 & 7.75E-15 & 2. $12 \mathrm{E}-12$ & $7.75 E-15$ & $2.12 \mathrm{E}-12$ & $-0.04 \%$ & $-0.16 \%$ \\
\hline 321.85 & $1.28 E-14$ & $2.48 \mathrm{E}-12$ & $1.28 E-14$ & $2.48 E-12$ & $-0.30 \%$ & $-0.09 \%$ \\
\hline 326.80 & $2.08 \mathrm{E}-14$ & $2.89 E-12$ & $2.08 E-14$ & $2.89 E-12$ & $-0.05 \%$ & $0.14 \%$ \\
\hline 331.75 & $3.31 E-14$ & $3.34 \mathrm{E}-12$ & $3.31 E-14$ & 3.34E-12 & $0.14 \%$ & $0.08 \%$ \\
\hline 336.70 & $5.15 E-14$ & $3.84 \mathrm{E}-12$ & $5.15 \mathrm{E}-14$ & $3.84 \mathrm{E}-12$ & $-0.02 \%$ & $0.02 \%$ \\
\hline 341.65 & $7.88 E-14$ & 4.40E-12 & $7.88 \mathrm{E}-14$ & $4.40 E-12$ & $-0.04 \%$ & $0.11 \%$ \\
\hline 346.60 & $1.19 E-13$ & $5.01 \mathrm{E}-12$ & $1.19 \mathrm{E}-13$ & $5.01 E-12$ & $0.33 \%$ & $0.05 \%$ \\
\hline 351.55 & $1.76 E-13$ & $5.68 \mathrm{E}-12$ & $1.76 E-13$ & $5.68 E-12$ & $0.23 \%$ & $0.02 \%$ \\
\hline 356.50 & $2.56 E-13$ & $6.41 E-12$ & $2.56 E-13$ & $6.41 \mathrm{E}-12$ & $0.00 \%$ & $-0.03 \%$ \\
\hline 361.45 & $3.68 \mathrm{E}-13$ & 7.21E-12 & $3.68 \mathrm{E}-13$ & 7.21E-12 & $0.04 \%$ & $0.01 \%$ \\
\hline 366.40 & $5.21 E-13$ & 8.07E-12 & $5.21 E-13$ & 8.07E-12 & $-0.06 \%$ & $-0.02 \%$ \\
\hline 371.35 & $7.29 E-13$ & $9.00 \mathrm{E}-12$ & $7.29 E-13$ & $9.00 \mathrm{E}-12$ & $-0.03 \%$ & $-0.03 \%$ \\
\hline 376.30 & $1.01 \mathrm{E}-12$ & $1.00 \mathrm{E}-11$ & $1.01 E-12$ & $1.00 \mathrm{E}-11$ & $0.25 \%$ & $-0.03 \%$ \\
\hline 381.25 & $1.38 \mathrm{E}-12$ & $1.11 \mathrm{E}-11$ & $1.38 \mathrm{E}-12$ & $1.11 E-11$ & $0.33 \%$ & $0.24 \%$ \\
\hline 386.20 & $1.86 E-12$ & $1.22 E-11$ & $1.86 \mathrm{E}-12$ & $1.22 \mathrm{E}-1.1$ & $0.17 \%$ & $-0.14 \%$ \\
\hline 391.15 & 2.48E-12 & $1.34 \mathrm{E}-11$ & $2.48 \mathrm{E}-12$ & $1.34 E-11$ & $0.00 \%$ & $-0.24 \%$ \\
\hline 396.10 & $3.28 \mathrm{E}-12$ & $1.47 E-11$ & 3.28E-12 & $1.47 \mathrm{E}-11$ & $0.05 \%$ & $-0.15 \%$ \\
\hline 401.05 & 4.29E-12 & $1.61 \mathrm{E}-11$ & $4.29 E-12$ & $1.61 E-11$ & $-0.05 \%$ & $0.10 \%$ \\
\hline 406.00 & $5.57 E-12$ & 1.75E-11 & $5.57 E-12$ & $1.75 E-11$ & $0.04 \%$ & $-0.13 \%$ \\
\hline 410.95 & $7.16 \mathrm{E}-12$ & $1.90 \mathrm{E}-11$ & $7.16 \mathrm{E}-12$ & $1.90 \mathrm{E}-11$ & $0.02 \%$ & $-0.18 \%$ \\
\hline 415.90 & $9.13 E-12$ & 2.06E-11 & $9.13 E-12$ & $2.06 \mathrm{E}-11$ & $0.05 \%$ & $-0.10 \%$ \\
\hline 420.85 & $1.15 \mathrm{E}-11$ & 2.23E-11 & $1.15 \mathrm{E}-11$ & $2.23 E-11$ & $-0.35 \%$ & $0.09 \%$ \\
\hline 425.80 & $1.45 E-11$ & $2.40 \mathrm{E}-11$ & $1.45 E-11$ & $2.40 \mathrm{E}-11$ & $0.13 \%$ & $-0.05 \%$ \\
\hline 430.75 & $1.80 \mathrm{E}-11$ & $2.58 \mathrm{E}-11$ & $1.80 E-11$ & $2.58 \mathrm{E}-11$ & $-0.21 \%$ & $-0.07 \%$ \\
\hline 435.70 & $2.23 \mathrm{E}-11$ & 2.77E-11 & 2.23E-11 & 2.77E-11 & $-0.05 \%$ & $0.01 \%$ \\
\hline 440.65 & $2.74 E-11$ & $2.96 \mathrm{E}-11$ & $2.74 \mathrm{E}-11$ & 2.96E-11 & $-0.03 \%$ & $-0.15 \%$ \\
\hline 445.60 & 3.35E-11 & $3.17 E-11$ & 3.35E-11 & $3.17 E-11$ & $0.14 \%$ & $0.11 \%$ \\
\hline 450.55 & $4.06 \mathrm{E}-11$ & $3.38 \mathrm{E}-11$ & $4.06 E-11$ & $3.38 \mathrm{E}-11$ & $0.06 \%$ & $0.14 \%$ \\
\hline 455.50 & $4.89 E-11$ & $3.59 E-11$ & $4.89 E-11$ & $3.59 E-11$ & $-0.05 \%$ & $-0.03 \%$ \\
\hline 460.45 & 5.87E-11 & $3.81 E-11$ & 5.87E-11 & $3.81 E-11$ & $0.07 \%$ & $-0.09 \%$ \\
\hline 465.40 & $6.99 E-11$ & $4.04 \mathrm{E}-11$ & $6.99 \mathrm{E}-11$ & $4.04 \mathrm{E}-11$ & $-0.06 \%$ & $-0.05 \%$ \\
\hline
\end{tabular}




\begin{tabular}{|c|c|c|c|c|c|c|}
\hline 470.35 & 8.30E-11 & $4.28 \mathrm{E}-11$ & 8.30E-11 & $4.28 E-11$ & $0.06 \%$ & \\
\hline 475.30 & $9.79 E-11$ & $4.52 E-11$ & $9.79 E-11$ & $4.52 \mathrm{E}-11$ & $0.01 \%$ & $0.02 \%$ \\
\hline 480.25 & $1.15 E-10$ & $4.77 \mathrm{E}-11$ & $1.15 E-10$ & 4.77E-11 & $0.04 \%$ & $0.06 \%$ \\
\hline & $1.34 \mathrm{E}-10$ & $5.02 \mathrm{E}-11$ & $1.34 \mathrm{E}-10$ & $5.02 E-11$ & $-0.27 \%$ & $-0.02 \%$ \\
\hline 490.15 & $1.56 \mathrm{E}-10$ & $5.28 E-11$ & $1.56 \mathrm{E}-10$ & $5.28 \mathrm{E}-11$ & $-0.22 \%$ & $-0.02 \%$ \\
\hline 495.10 & $1.81 \mathrm{E}-10$ & $5.55 E-11$ & $1.81 \mathrm{E}-10$ & $5.55 E-11$ & $-0.08 \%$ & $0.05 \%$ \\
\hline 500.05 & $2.84 E-10$ & $6.06 E-11$ & $2.84 \mathrm{E}-10$ & $6.06 \mathrm{E}-11$ & $0.08 \%$ & $-0.03 \%$ \\
\hline & $3.42 E-10$ & $6.39 E-11$ & $3.23 E-10$ & $6.34 \mathrm{E}-11$ & $5.61 \%$ & $0.74 \%$ \\
\hline 509.95 & $3.66 \mathrm{E}-10$ & $6.33 E-11$ & $3.66 E-10$ & $6.33 E-11$ & $-0.02 \%$ & $0.02 \%$ \\
\hline & $4.14 E-10$ & $1 E-11$ & $4.14 E-10$ & $6.61 E-11$ & $0.04 \%$ & $-0.02 \%$ \\
\hline & $4.66 E-10$ & $6.90 E-111$ & $4.66 \mathrm{E}-10$ & $6.90 E-11$ & $-0.06 \%$ & $0.02 \%$ \\
\hline & $5.24 E-10$ & $7.19 E-11$ & $5.24 E-10$ & $7.19 E-11$ & $0.06 \%$ & $-0.02 \%$ \\
\hline & $5.86 E-10$ & $7.49 E-11$ & $5.86 \mathrm{E}-10$ & $7.49 E-11$ & $-0.08 \%$ & $0.01 \%$ \\
\hline & $E-10$ & $7.87 E-11$ & $5.12 \mathrm{E}-10$ & $7.87 E-11$ & $-0.07 \%$ & $-0.05 \%$ \\
\hline & $E-10$ & $8.19 E-11$ & $5.75 \mathrm{E}-10$ & $8.19 E-11$ & $0.06 \%$ & $0.02 \%$ \\
\hline & $E-10$ & & & & & $0.02 \%$ \\
\hline & $6 E-10$ & $E-11$ & $6 \mathrm{E}-10$ & $3.83 E-11$ & $-0 . c$ & $-0.04 \%$ \\
\hline & $7.96 \mathrm{E}-10$ & $8.78 E-11$ & $7.96 \mathrm{E}-10$ & $8.78 E-11$ & $-0.06 \%$ & $0.02 \%$ \\
\hline & $83 E-10$ & $9.10 E-11$ & $8.83 E-10$ & $9.10 \mathrm{E}-11$ & -0.02 & $-0.04 \%$ \\
\hline & 10 & $E-11$ & 9.7 & $9.43 E-11$ & $0.03 \%$ & $-0.03 \%$ \\
\hline & -09 & -11 & 1. & $=-11$ & $0.24 \%$ & $0.03 \%$ \\
\hline & $1.19 E-09$ & $E-1.0$ & $9 E-09$ & $I E-10$ & 0.3 & $-0.07 \%$ \\
\hline & $1.30 E-09$ & $1.05 E-10$ & OE-09 & $1.05 E-10$ & $-0.13 \%$ & $0.46 \%$ \\
\hline 584.20 & $1.43 E-09$ & $1.08 \mathrm{E}-10$ & $3 E-09$ & $1.08 E-10$ & 0.3 & $-0.01 \%$ \\
\hline & $E-09$ & $=-10$ & $=-09$ & $1.12 E-10$ & $0.12 \%$ & $0.40 \%$ \\
\hline & -09 & -10 & $i$. & $E-10$ & $0.04 \%$ & $-0.13 \%$ \\
\hline 5 & $1.85 E-09$ & $E-10$ & $5 E-09$ & $1.19 E-10$ & $0.04 \%$ & $0.17 \%$ \\
\hline 604.00 & 2.01E-09 & $1.22 \mathrm{E}-10$ & $1 E-09$ & $1.22 \mathrm{E}-10$ & $0.07 \%$ & $-0.41 \%$ \\
\hline & $2.18 \mathrm{E}-09$ & $1.26 E-10$ & $8 \mathrm{E}-09$ & $1.26 E-10$ & $0.13 \%$ & $-0.19 \%$ \\
\hline & -09 & $=-10$ & $\mathrm{E}-09$ & $E-10$ & $9 \%$ & $-0.03 \%$ \\
\hline & 2.54 & -10 & $4 E-09$ & & -0.1 & $0.08 \%$ \\
\hline 623.80 & $2.74 \mathrm{E}-09$ & $1.38 \mathrm{E}-10$ & 2.74E-09 & $E-10$ & & $0.15 \%$ \\
\hline & 2.95E-09 & $1.42 E-10$ & 2.95E-09 & $1.42 E-10$ & -0.0 & $0.18 \%$ \\
\hline & $3.17 E-09$ & $1.46 E-10$ & 3.17E-09 & $1.46 E-10$ & $-0.01 \%$ & $0.17 \%$ \\
\hline & -09 & $E-10$ & OE-09 & 1.5 & -0. & $0.13 \%$ \\
\hline 643.60 & $3.64 E-09$ & $1.54 E-10$ & $3.64 E-09$ & $E-10$ & $-0.04 \%$ & $0.06 \%$ \\
\hline 648.55 & $3.89 E-09$ & $1.58 E-10$ & $3.89 E-09$ & $1.58 \mathrm{E}-10$ & $-0.09 \%$ & $-0.04 \%$ \\
\hline & 4.16E-09 & $1.62 E-10$ & 4.16E-09 & $1.62 E-10$ & $0.07 \%$ & $-0.17 \%$ \\
\hline & -09 & & 4.4 & $1.67 E-10$ & $-0.04 \%$ & $0.27 \%$ \\
\hline & $4.72 E-09$ & $E-10$ & 4.72E-09 & $1.71 \mathrm{E}-10$ & $0.04 \%$ & $0.08 \%$ \\
\hline & 5.02E-09 & $1.75 E-10$ & $5.02 E-09$ & $1.75 E-10$ & $0.08 \%$ & $-0.13 \%$ \\
\hline 673.30 & 5.33E-09 & $1.80 E-10$ & $5.33 E-09$ & $1.80 E-10$ & $0.08 \%$ & $0.20 \%$ \\
\hline & 5:65E-09 & $1.84 E-10$ & 5.65E-09 & $1.84 \mathrm{E}-10$ & $0.05 \%$ & $-0.07 \%$ \\
\hline & $5.98 \mathrm{E}-09$ & $1.89 E-10$ & 5.98E-09 & $1.89 E-10$ & $-0.01 \%$ & $0.19 \%$ \\
\hline & $6.33 E-09$ & $1.93 E-10$ & 6.33E-09 & $1.93 E-10$ & $0.06 \%$ & $-0.12 \%$ \\
\hline 693.10 & $6.68 \mathrm{E}-09$ & $1.98 \mathrm{E}-10$ & 6.68E-09 & $1.98 E-10$ & $-0.05 \%$ & $0.07 \%$ \\
\hline & 7.05E-09 & $2.03 E-10$ & 7.05E-09 & $2.03 \mathrm{E}-10$ & $-0.04 \%$ & $0.23 \%$ \\
\hline & 7.43E-09 & & & & $-0.05 \%$ & $-0.13 \%$ \\
\hline 707.95 & 7.83E-09 & 2.12E-10 & 7.83E-09 & $2.12 \mathrm{E}-10$ & $0.03 \%$ & $-0.03 \%$ \\
\hline
\end{tabular}




\begin{tabular}{|c|c|c|c|c|c|c|}
\hline 712.90 & 8.39E-09 & $2.19 E-10$ & 8.39E-09 & 2.19E-10 & $0.05 \%$ & $-0.07 \%$ \\
\hline 717.85 & $9.01 E-09$ & 2.27E-10 & $9.01 E-09$ & 2.27E-10 & $0.00 \%$ & $0.00 \%$ \\
\hline 722.80 & 9.67E-09 & 2.35E-10 & 9.67E-09 & $2.35 E-10$ & $0.05 \%$ & $-0.01 \%$ \\
\hline 727.75 & $1.04 E-08$ & $2.43 E-10$ & $1.04 \mathrm{E}-08$ & $2.43 E-10$ & $0.46 \%$ & $-0.11 \%$ \\
\hline 732.70 & $1.11 \mathrm{E}-08$ & 2.52E-10 & $1.11 \mathrm{E}-08$ & $2.52 \mathrm{E}-10$ & $0.26 \%$ & $0.12 \%$ \\
\hline 737.65 & $1.18 \mathrm{E}-08$ & 2.60E-10 & $1.18 \mathrm{E}-08$ & $2.60 \mathrm{E}-10$ & $-0.18 \%$ & $-0.13 \%$ \\
\hline 742.60 & $1.26 E-08$ & 2.69E-10 & 1.26E-08 & $2.69 E-10$ & $-0.04 \%$ & $-0.07 \%$ \\
\hline 747.55 & $1.34 \mathrm{E}-08$ & $2.78 \mathrm{E}-10$ & 1.34E-08 & $2.78 \mathrm{E}-10$ & $-0.16 \%$ & $-0.08 \%$ \\
\hline 752.50 & $1.43 E-08$ & $2.87 E-10$ & $1.43 E-08$ & $2.87 E-10$ & $0.21 \%$ & $-0.17 \%$ \\
\hline 757.45 & $1.52 E-08$ & 2.97E-10 & $1.52 E-08$ & $2.97 E-10$ & $0.30 \%$ & $0.02 \%$ \\
\hline 762.40 & 1.61E-08 & 3.07E-10 & 1.61E-08 & $3.07 E-10$ & $0.18 \%$ & $0.12 \%$ \\
\hline 767.35 & $1.70 \mathrm{E}-08$ & $3.16 \mathrm{E}-10$ & $1.70 \mathrm{E}-08$ & $3.16 \mathrm{E}-10$ & $-0.13 \%$ & $-0.16 \%$ \\
\hline 772.30 & $1.80 E-08$ & 3.27E-10 & 1.80E-08 & $3.27 E-10$ & $-0.03 \%$ & $0.13 \%$ \\
\hline 777.25 & $1.90 \mathrm{E}-08$ & 3.37E-10 & 1.90E-08 & 3.37E-10 & $-0.13 \%$ & $0.03 \%$ \\
\hline 782.20 & 2.01E-08 & 3.47E-10 & 2.01E-08 & $3.47 \mathrm{E}-10$ & $0.11 \%$ & $-0.12 \%$ \\
\hline 787.15 & 2.12E-08 & $3.58 \mathrm{E}-10$ & 2.12E-08 & $3.58 E-10$ & $0.16 \%$ & $-0.04 \%$ \\
\hline 792.10 & 2.23E-08 & $3.69 \mathrm{E}-10$ & 2.23E-08 & $3.69 E-10$ & $0.06 \%$ & $-0.02 \%$ \\
\hline 797.05 & $2.34 \mathrm{E}-08$ & 3.80E-10 & 2.34E-08 & $3.80 E-10$ & $-0.18 \%$ & $-0.06 \%$ \\
\hline 802.00 & 2.46E-08 & $3.92 E-10$ & $2.46 E-08$ & $3.92 \mathrm{E}-10$ & $-0.13 \%$ & $0.11 \%$ \\
\hline 806.95 & 2.59E-08 & $4.03 E-10$ & 2.59E-08 & $4.03 E-10$ & $0.17 \%$ & $-0.03 \%$ \\
\hline 811.90 & 2.71E-08 & $4.15 E-10$ & 2.71E-08 & $4.15 \mathrm{E}-10$ & $-0.04 \%$ & $0.03 \%$ \\
\hline 816.85 & 2.84E-08 & $4.27 E-10$ & $2.84 E-08$ & $4.27 E-10$ & $-0.01 \%$ & $0.03 \%$ \\
\hline 821.80 & 2.97E-08 & 4.39E-10 & 2.97E-08 & $4.39 E-10$ & $-0.08 \%$ & $0.00 \%$ \\
\hline 826.75 & 3.11E-08 & $4.51 E-10$ & $3.11 \mathrm{E}-08$ & $4.51 E-10$ & $0.06 \%$ & $-0.09 \%$ \\
\hline 831.70 & $3.25 E-08$ & $4.64 E-10$ & $3.25 E-08$ & $4.64 E-10$ & $0.10 \%$ & $0.01 \%$ \\
\hline 836.65 & 3.39E-08 & 4.77E-10 & 3.39E-08 & 4.77E-10 & $0.04 \%$ & $0.06 \%$ \\
\hline 841.60 & 3.53E-08 & $4.90 E-10$ & $3.53 E-08$ & $4.90 E-10$ & $-0.11 \%$ & $0.06 \%$ \\
\hline 846.55 & $3.68 \mathrm{E}-08$ & $5.03 E-10$ & 3.68E-08 & $5.03 E-10$ & $-0.06 \%$ & $0.03 \%$ \\
\hline 851.50 & $3.83 E-08$ & $5.16 \mathrm{E}-10$ & 3.83E-08 & $5.16 \mathrm{E}-10$ & $-0.09 \%$ & $-0.03 \%$ \\
\hline 856.45 & 3.99E-08 & $5.30 \mathrm{E}-10$ & $3.99 E-08$ & $5.30 \mathrm{E}-10$ & $0.06 \%$ & $0.06 \%$ \\
\hline 861.40 & 4.14E-08 & $5.43 \mathrm{E}-10$ & 4.15E-08 & $5.43 E-10$ & $-0.12 \%$ & $-0.07 \%$ \\
\hline 866.35 & $4.31 \mathrm{E}-08$ & $5.57 E-10$ & 4.31E-08 & $5.57 E-10$ & $0.11 \%$ & $-0.05 \%$ \\
\hline 871.30 & 4.47E-08 & 5.71E-10 & 4.47E-08 & $5.71 E-10$ & $0.04 \%$ & $-0.06 \%$ \\
\hline 876.25 & $4.63 E-08$ & $5.86 E-10$ & 4.63E-08 & $5.86 \mathrm{E}-10$ & $-0.08 \%$ & $0.07 \%$ \\
\hline & 4.80E-08 & 6.00E-10 & 4.80E-08 & $6.00 \mathrm{E}-10$ & $-0.05 \%$ & $0.00 \%$ \\
\hline 886.15 & 4.97E-08 & $6.15 E-10$ & 4.97E-08 & $6.15 \mathrm{E}-10$ & $-0.07 \%$ & $0.07 \%$ \\
\hline 891.10 & $5.15 \mathrm{E}-08$ & $6.29 E-10$ & $5.15 E-08$ & $6.29 E-10$ & $0.05 \%$ & $-0.04 \%$ \\
\hline 896.05 & 5.32E-08 & $6.44 E-10$ & $5.32 \mathrm{E}-08$ & $6.44 \mathrm{E}-10$ & $-0.07 \%$ & $-0.02 \%$ \\
\hline 901.00 & 5.50E-08 & $6.59 \mathrm{E}-10$ & $5.50 E-08$ & $6.59 E-10$ & $-0.04 \%$ & $-0.03 \%$ \\
\hline 905.95 & $5.68 \mathrm{E}-08$ & $6.74 E-10$ & $5.68 E-08$ & $6.74 E-10$ & $-0.06 \%$ & $-0.05 \%$ \\
\hline 910.90 & 5.87E-08 & $6.90 E-10$ & 5.87E-08 & $6.90 \mathrm{E}-10$ & $0.06 \%$ & $0.04 \%$ \\
\hline 915.85 & $6.05 E-08$ & $7.05 E-10$ & 6.05E-08 & $7.05 E-10$ & $-0.04 \%$ & $-0.02 \%$ \\
\hline 920.80 & $6.24 E-08$ & 7.21E-10 & $6.24 \mathrm{E}-08$ & $7.21 E-10$ & $0.00 \%$ & $0.03 \%$ \\
\hline 925.75 & $6.43 E-08$ & $7.36 \mathrm{E}-10$ & $6.43 E-08$ & 7.37E-10 & $0.00 \%$ & $-0.07 \%$ \\
\hline 930.70 & $6.62 \mathrm{E}-08$ & $7.52 E-10$ & 6.62E-08 & $7.52 E-10$ & $-0.03 \%$ & $-0.05 \%$ \\
\hline 935.65 & $6.82 \mathrm{E}-08$ & $7.68 \mathrm{E}-10$ & $6.82 E-08$ & $7.68 \mathrm{E}-10$ & $0.06 \%$ & $-0.05 \%$ \\
\hline 940.60 & 7.01E-08 & $7.84 E-10$ & 7.01E-08 & $7.84 \mathrm{E}-10$ & $-0.02 \%$ & $-0.06 \%$ \\
\hline 945.55 & $7.21 E-08$ & 8.01E-10 & $7.21 \mathrm{E}-08$ & $8.01 E-10$ & $0.02 \%$ & $0.04 \%$ \\
\hline 950.50 & 7.41E-08 & $8.17 \mathrm{E}-10$ & 7.41E-08 & $8.17 \mathrm{E}-10$ & $0.03 \%$ & $0.00 \%$ \\
\hline
\end{tabular}




$\begin{array}{rrrrrrr}955.45 & 7.61 \mathrm{E}-08 & 8.33 \mathrm{E}-10 & 7.61 \mathrm{E}-08 & 8.33 \mathrm{E}-10 & 0.02 \% & -0.06 \% \\ 960.40 & 7.81 \mathrm{E}-08 & 8.50 \mathrm{E}-10 & 7.81 \mathrm{E}-08 & 8.50 \mathrm{E}-10 & -0.01 \% & 0.00 \% \\ 965.35 & 8.01 \mathrm{E}-08 & 8.67 \mathrm{E}-10 & 8.01 \mathrm{E}-08 & 8.67 \mathrm{E}-10 & -0.06 \% & 0.04 \% \\ 970.30 & 8.22 \mathrm{E}-08 & 8.83 \mathrm{E}-10 & 8.22 \mathrm{E}-08 & 8.83 \mathrm{E}-10 & 0.01 \% & -0.04 \% \\ 975.25 & 8.43 \mathrm{E}-08 & 9.00 \mathrm{E}-10 & 8.43 \mathrm{E}-08 & 9.00 \mathrm{E}-10 & 0.05 \% & -0.02 \% \\ 980.20 & 8.63 \mathrm{E}-08 & 9.17 \mathrm{E}-10 & 8.63 \mathrm{E}-08 & 9.17 \mathrm{E}-10 & -0.04 \% & -0.01 \% \\ 985.15 & 8.84 \mathrm{E}-08 & 9.34 \mathrm{E}-10 & 8.84 \mathrm{E}-08 & 9.34 \mathrm{E}-10 & -0.03 \% & -0.01 \% \\ 990.10 & 9.05 \mathrm{E}-08 & 9.51 \mathrm{E}-10 & 9.05 \mathrm{E}-08 & 9.51 \mathrm{E}-10 & -0.03 \% & -0.02 \% \\ 995.05 & 9.26 \mathrm{E}-08 & 9.68 \mathrm{E}-10 & 9.26 \mathrm{E}-08 & 9.68 \mathrm{E}-10 & -0.03 \% & -0.03 \%\end{array}$


Table A3. Results for Test Case 1 (Release Height $=55 \mathrm{~m}$ )

\begin{tabular}{|c|c|c|c|c|c|c|}
\hline & VENTSAR & & ENTSAR XL & & & \\
\hline & $\begin{array}{c}99.50 \% \\
X / Q\end{array}$ & $\begin{array}{l}\text { Annual } \\
\text { Average }\end{array}$ & $\begin{array}{c}99.50 \% \\
X / Q\end{array}$ & $\begin{array}{l}\text { Annual } \\
\text { Average }\end{array}$ & $\begin{array}{l}\% \text { Diff } \\
X / Q\end{array}$ & $\begin{array}{l}\text { \% Diff } \\
\text { Ann Ave }\end{array}$ \\
\hline 10.00 & $0.00 E+00$ & $0.00 E+00$ & $0.00 \mathrm{E}+00$ & $0.00 E+00$ & $\star \star$ & $\star \star$ \\
\hline 14.95 & $0.00 E+00$ & $0.00 E+00$ & $0.00 E+00$ & $0.00 E+00$ & $\star \star$ & $\star \star$ \\
\hline 19.90 & $0.00 E+00$ & $0.00 E+00$ & $0.00 E+00$ & $3.40 E-219$ & $\star \star$ & ** \\
\hline 24.85 & $0.00 E+00$ & $0.00 E+00$ & $0.00 E+00$ & $4.22 E-157$ & $\star *$ & ** \\
\hline 29.80 & $0.00 E+00$ & $0.00 E+00$ & $2.28 E-233$ & $1.34 E-120$ & $* *$ & $* *$ \\
\hline 34.75 & $0.00 E+00$ & $0.00 E+00$ & $1.21 E-183$ & $4.65 E-97$ & $\star *$ & $\star \star$ \\
\hline 39.70 & $0.00 E+00$ & $0.00 E+00$ & $1.18 E-149$ & 7.37E-81 & $\star \star$ & . $\quad \star$ \\
\hline 44.65 & $0.00 E+00$ & 3.71E-69 & $3.03 E-125$ & 3.69E-69 & $\star \star$ & $0.59 \%$ \\
\hline 49.60 & $0.00 E+00$ & $2.18 \mathrm{E}-60$ & 4.87E-107 & 2.17E-60 & $* *$ & $0.31 \%$ \\
\hline 54.55 & $0.00 E+00$ & $1.29 E-53$ & $4.84 \mathrm{E}-93$ & $1.29 E-53$ & $* *$ & $0.33 \%$ \\
\hline 59.50 & $0.00 E+00$ & $2.93 E-48$ & $5.17 E-82$ & 2.92E-48 & ** & $0.26 \%$ \\
\hline 64.45 & $0.00 E+00$ & $6.16 \mathrm{E}-44$ & $3.83 E-73$ & $6.14 E-44$ & $\star \star$ & $0.31 \%$ \\
\hline 69.40 & $0.00 E+00$ & $2.17 E-40$ & 6.91E-66 & $2.17 E-40$ & $\star \star$ & $0.22 \%$ \\
\hline 74.35 & $0.00 E+00$ & $1.95 \mathrm{E}-37$ & $3.65 E-82$ & $1.94 \mathrm{E}-37$ & $\star \star$ & $0.28 \%$ \\
\hline 79.30 & $1.97 E-75$ & $6.02 E-35$ & $1.96 \mathrm{E}-75$ & $6.00 E-35$ & $0.60 \%$ & $0.29 \%$ \\
\hline 84.25 & $1.41 E-69$ & $7.96 \mathrm{E}-33$ & 1.40E-69 & $7.94 \mathrm{E}-33$ & $0.93 \%$ & $0.27 \%$ \\
\hline 89.20 & $1.71 E-64$ & $5.32 E-31$ & $1.70 \mathrm{E}-64$ & $5.31 E-31$ & $0.80 \%$ & $0.25 \%$ \\
\hline 94.15 & $4.61 E-60$ & $2.04 E-29$ & $4.59 E-60$ & $2.03 E-29$ & $0.44 \%$ & $0.31 \%$ \\
\hline 99.10 & $3.55 E-56$ & $4.94 E-28$ & $3.53 E-56$ & 4.93E-28 & $0.59 \%$ & $0.27 \%$ \\
\hline 104.05 & 4.55E-52 & 1.37E-26 & $4.55 E-52$ & $1.37 \mathrm{E}-26$ & $0.09 \%$ & $0.04 \%$ \\
\hline 109.00 & 2.60E-48 & $3.00 \mathrm{E}-25$ & $2.60 E-48$ & $3.00 \mathrm{E}-25$ & $0.12 \%$ & $-0.06 \%$ \\
\hline 113.95 & $5.13 \mathrm{E}-45$ & $4.48 \mathrm{E}-24$ & $5.13 \mathrm{E}-45$ & $4.48 E-24$ & $0.05 \%$ & $0.00 \%$ \\
\hline 118.90 & 4.14E-42 & $4.84 E-23$ & $4: 14 \mathrm{E}-42$ & $4.84 E-23$ & $0.11 \%$ & $-0.01 \%$ \\
\hline 123.85 & $1.56 E-39$ & $3.98 E-22$ & $1.56 E-39$ & $3.98 E-22$ & $-0.15 \%$ & $0.03 \%$ \\
\hline 128.80 & $3.09 E-37$ & 2.59E-21 & $3.09 E-37$ & 2.59E-21 & $-0.04 \%$ & $-0.03 \%$ \\
\hline 133.75 & $3.51 E-35$ & $1.38 \mathrm{E}-20$ & $3.51 E-35$ & $1.38 \mathrm{E}-20$ & $-0.01 \%$ & $-0.10 \%$ \\
\hline 138.70 & $2.47 E-33$ & $6.20 \mathrm{E}-20$ & 2.47E-33 & $6.20 \mathrm{E}-20$ & $0.05 \%$ & $0.01 \%$ \\
\hline 143.65 & $1.15 \mathrm{E}-31$ & 2.40E-19 & $1.15 \mathrm{E}-31$ & 2.40E-19 & $0.39 \%$ & $0.18 \%$ \\
\hline 148.60 & $3.70 \mathrm{E}-30$ & 8.13E-19 & $3.70 E-30$ & $8.13 E-19$ & $0.06 \%$ & $0.03 \%$ \\
\hline 153.55 & 8.68E-29 & $2.46 E-18$ & 8.68E-29 & $2.46 \mathrm{E}-18$ & $-0.05 \%$ & $0.00 \%$ \\
\hline 158.50 & $1.54 E-27$ & $6.73 E-18$ & $1.54 \mathrm{E}-27$ & $6.73 E-18$ & $-0.12 \%$ & $-0.07 \%$ \\
\hline 16 & 2.14E-26 & $1.69 \mathrm{E}-17$ & $2: 14 E-26$ & 1.69E-17 & $0.13 \%$ & $0.13 \%$ \\
\hline 168.40 & $2.38 \mathrm{E}-25$ & $3.91 \mathrm{E}-17$ & 2.38E-25 & $3.91 \mathrm{E}-17$ & $0.05 \%$ & $-0.02 \%$ \\
\hline 173.35 & $2.18 E-24$ & $8.45 E-17$ & $2.18 \mathrm{E}-24$ & $8.45 E-17$ & $0.12 \%$ & $-0.03 \%$ \\
\hline 178.30 & $1.67 E-23$ & $1.72 E-16$ & $1.67 E-23$ & $1.72 \mathrm{E}-16$ & $-0.21 \%$ & $0.16 \%$ \\
\hline 183.25 & $1.10 \mathrm{E}-22$ & $3.30 \mathrm{E}-16$ & 1.10E-22 & 3.30E-16 & $0.01 \%$ & $-0.03 \%$ \\
\hline 188.20 & $6.28 \mathrm{E}-22$ & $6.04 E-16$ & $6.28 E-22$ & $6.04 \mathrm{E}-16$ & $0.01 \%$ & $0.01 \%$ \\
\hline 193.15 & $3.16 \mathrm{E}-21$ & $1.06 \mathrm{E}-15$ & $3.16 \mathrm{E}-21$ & $1.06 \mathrm{E}-15$ & $0.08 \%$ & $0.26 \%$ \\
\hline 198.10 & $1.42 E-20$ & $1.78 \mathrm{E}-15$ & $1.42 \mathrm{E}-20$ & $1.78 E-15$ & $0.31 \%$ & $0.07 \%$ \\
\hline & $5.72 E-20$ & $2.89 E-15$ & $5.72 E-20$ & $2.89 E-15$ & $0.02 \%$ & $0.06 \%$ \\
\hline & 2.10E-19 & $4.54 E-15$ & 2.10E-19 & $4.54 E-15$ & $-0.09 \%$ & $-0.07 \%$ \\
\hline 2.95 & 7.09E-19 & $6.94 E-15$ & 7.09E-19 & $6.94 E-15$ & $0.04 \%$ & $-0.06 \%$ \\
\hline & $2.21 E-18$ & $1: 03 E-14$ & $2.21 E-18$ & $1.03 E-14$ & $0.04 \%$ & $0.27 \%$ \\
\hline & $6.41 E-18$ & $1.51 E-14$ & $6.41 E-18$ & $1.51 E-14$ & $0.03 \%$ & $0.14 \%$ \\
\hline
\end{tabular}




\begin{tabular}{|c|c|c|c|c|c|c|}
\hline 27.80 & $1.74 \mathrm{E}-17$ & $2.15 E-14$ & $1.74 E-17$ & $2.15 E-14$ & $0.00 \%$ & $-0.14 \%$ \\
\hline 232.75 & $4.45 E-17$. & $3.00 E-14$ & $4.45 E-17$ & $3.00 E-14$ & $0.06 \%$ & $-0.08 \%$ \\
\hline 37.70 & $1.08 \mathrm{E}-16$ & $4.13 E-14$ & $1.08 E-16$ & $4.13 E-14$ & $0.45 \%$ & $0.00 \%$ \\
\hline 42.65 & 2.47E-16 & $5.60 E-14$ & $2.47 E-16$ & $5.60 E-14$ & $0.05 \%$ & $-0.03 \%$ \\
\hline 47.60 & $5.41 E-16$ & $7.48 \mathrm{E}-14$ & $5.41 E-16$ & $7.48 E-14$ & $0.07 \%$ & $0.00 \%$ \\
\hline 52.55 & $1.13 E-15$ & $9.87 E-14$ & $1.13 E-1.5$ & $9.87 E-14$ & $-0.27 \%$ & $0.25 \%$ \\
\hline & $2.28 \mathrm{E}-15$ & $1.29 E-13$ & $2.28 E-15$ & $1.29 E-13$ & $-0.01 \%$ & $0.03 \%$ \\
\hline & $4.42 E-15$ & $1.66 \mathrm{E}-13$ & $4.42 E-15$ & $1.66 E-13$ & $0.02 \%$ & $0.05 \%$ \\
\hline 57.4 & $8.27 E-15$ & $2.12 E-13$ & 8.27E-15 & 2.12E-13 & $0.00 \%$ & $-0.01 \%$ \\
\hline 2.3 & $1.50 \mathrm{E}-14$ & $2.68 E-13$ & $1.50 \mathrm{E}-14$ & $2.68 E-13$ & $0.13 \%$ & $-0.01 \%$ \\
\hline & $2.63 E-14$ & $3.36 \mathrm{E}-13$ & 2.63E-14 & $3.36 E-13$ & $-0.09 \%$ & $-0.01 \%$ \\
\hline & $4.50 E-14$ & $4.18 \mathrm{E}$ & $4.50 E-14$ & $4.18 E-13$ & $0.08 \%$ & $0.05 \%$ \\
\hline 37 & $7.48 E-14$ & $5.15 \mathrm{E}-13$ & $7.48 E-14$ & $5.15 E-13$ & $-0.01 \%$ & $-0.06 \%$ \\
\hline & $1.21 E-13$ & $6.31 \mathrm{E}-13$ & $1.21 E-13$ & 6.31E-13 & -0.3 & 0.0 \\
\hline & $1.93 E-13$ & $7.67 E-13$ & $1.93 E-13$ & $7.67 E-13$ & $0.22 \%$ & 0.04 \\
\hline & $2.99 E-13$ & 9.2 & $2.99 E$ & $9.25 E-13$ & $0.04 \%$ & $-0.05 \%$ \\
\hline 0 & $4.55 E-13$ & & 4.55 & $1.11 E-12$ & $0.10 \%$ & $0.04 \%$ \\
\hline .9 & $6.78 E-13$ & $1.32 E-12$ & $6.78 E-13$ & 1.32E-12 & -0.0 & -0.1 \\
\hline & $9.94 E-13$ & $1.57 E-1.2$ & $9.94 E-13$ & $1.57 E-12$ & 0.0 & $0.31 \%$ \\
\hline & $1.43 \mathrm{E}-12$ & $1.84 E-12$ & $1.43 \mathrm{E}-12$ & $1.84 E-12$ & $-0.16 \%$ & $-0.12 \%$ \\
\hline .80 & 2.03E-12 & 2.1 & 2.0 & $=-12$ & $-0.08 \%$ & $0.19 \%$ \\
\hline & 2.84E-12 & $2.51 \mathrm{E}-12$ & 2.84 & $1 E-12$ & $0.05 \%$ & $0.04 \%$ \\
\hline & $3.91 \mathrm{E}-12$ & 2.90E-12 & $3.91 E-12$ & 2.90E-12 & $-0.02 \%$ & -0.1 \\
\hline & $5.32 E-12$ & 3.3 & 5.32 & $3.35 E-12$ & $0.06 \%$ & $0.14 \%$ \\
\hline & $7.14 E-12$ & 3.8 & 7.1 & -12 & $0.03 \%$ & $-0.10 \%$ \\
\hline & $9.47 E-12$ & $4.37 \mathrm{E}$ & 9.47 & -12 & $0.01 \%$ & -0. \\
\hline & $1.24 \mathrm{E}-11$ & $4.96 E-12$ & 1.24 & $=-12$ & $-0.17 \%$ & -0.1 \\
\hline & $1.61 \mathrm{E}-11$ & 5.611 & $1.61 E-11$ & $5.61 E-12$ & $-0.12 \%$ & $-0.04 \%$ \\
\hline & $2.07 E-11$ & 6.3 & 2.0 & $6.32 E-12$ & $-0.05 \%$ & $0.05 \%$ \\
\hline & 2.64E-11 & $7.08 \mathrm{E}-12$ & 2.6 & -12 & $0.17 \%$ & $-0.01 \%$ \\
\hline & $3.32 E-11$ & $7.91 E-12$ & $3.32 E-11$ & $7.91 E-12$ & $-0.10 \%$ & $0.04 \%$ \\
\hline & 4.15E-11 & $8.79 E$ & $4.15 E-11$ & 8.79E-12 & $-0.12 \%$ & $-0.06 \%$ \\
\hline & 5.15 & 9.7 & 5.1 & -12 & $-0.04 \%$ & $0.02 \%$ \\
\hline & $6.34 \mathrm{E}-1.1$ & $1.08 \mathrm{E}-11$ & 6.3 & & $0.03 \%$ & $0.31 \%$ \\
\hline & $7.74 \mathrm{E}-1$ & 1.1 & $7.74 \mathrm{E}-11$ & $1.19 E-11$ & $-0.01 \%$ & $0.41 \%$ \\
\hline & 9.39E-11 & 1.30 & $E-11$ & $1.30 \mathrm{E}-11$ & $0.04 \%$ & $-0.03 \%$ \\
\hline & 1.13 & 1.4 & 1.1 & $1.42 \mathrm{E}-11$ & $-0.05 \%$ & $-0.17 \%$ \\
\hline & $1.35 E-10$ & 1.5 & $=-10$ & -11 & $-0.22 \%$ & $-0.08 \%$ \\
\hline & $1.61 \mathrm{E}-10$ & & $1 E-10$ & $1.69 E-11$ & $0.04 \%$ & $0.18 \%$ \\
\hline & $1.90 \mathrm{E}-10$ & 1.8 & 1.9 & $1.83 \mathrm{E}-11$ & $-0.17 \%$ & $0.02 \%$ \\
\hline & $2.24 \mathrm{E}-10$ & 1.98 & 2.2 & $=-11$ & $0.09 \%$ & $0.04 \%$ \\
\hline & $2.62 E-10$ & 2. $14 \mathrm{E}-11$ & 2.62E-10 & $2.14 \mathrm{E}-11$ & $0.08 \%$ & $0.21 \%$ \\
\hline & $3.05 E-10$ & 2.30E-11 & $3.05 E-10$ & $2.30 \mathrm{E}-11$ & $0.11 \%$ & $0.06 \%$ \\
\hline & $3.53 E-10$ & 2.47E-11 & $3.53 E-10$ & 2.47E-11 & $0.04 \%$ & $0.05 \%$ \\
\hline & $4.07 E-10$ & 2.65्E-11 & $4.07 E-10$ & 2.65E-11 & $0.06 \%$ & $0.18 \%$ \\
\hline & 4.67E-10 & $2.83 \mathrm{E}-11$ & 4.67E-10 & 2.83E-11 & $0.04 \%$ & $0.05 \%$ \\
\hline & $5.33 \mathrm{E}-10$ & $3.02 E-11$ & 5.33E-10 & $3.02 E-11$ & $-0.08 \%$ & $0.06 \%$ \\
\hline & $6.07 \mathrm{E}-10$ & $3.21 \mathrm{E}-11$ & $6.07 \mathrm{E}-10$ & $3.21 E-11$ & $-0.01 \%$ & $-0.14 \%$ \\
\hline & $6.88 \mathrm{E}-10$ & $-3.42 E-11$ & $6.88 \mathrm{E}-10$ & $-3.42 E-11$ & $-0.03 \%$ & $0.08 \%$ \\
\hline
\end{tabular}




\begin{tabular}{|c|c|c|c|c|c|c|}
\hline 470.35 & 7.77E-10 & $3.63 E-11$ & 7.77E-10 & $3.63 E-11$ & $-0.02 \%$ & $0.11 \%$ \\
\hline 475.30 & 8.75E-10 & $3.84 \mathrm{E}-11$ & $8.75 E-10$ & $3.84 \mathrm{E}-11$ & $0.05 \%$ & $-0.03 \%$ \\
\hline 480.25 & $9.81 E-10$ & 4.06E-11 & $9.81 E-10$ & 4.06E-11 & $0.03 \%$ & $-0.06 \%$ \\
\hline 485.20 & $1.10 \mathrm{E}-09$ & $4.29 E-11$ & $1.10 \mathrm{E}-09$ & $4: 29 E-11$ & $0.35 \%$ & $0.01 \%$ \\
\hline 490.15 & 1.22E-09 & $4.52 E-11$ & $1.22 E-09$ & $4.52 E-11$ & $-0.09 \%$ & $-0.06 \%$ \\
\hline 495.10 & 1.36E-09 & $4.76 E-11$ & 1.36E-09 & $4.76 E-11$ & $0.27 \%$ & $-0.03 \%$ \\
\hline 500.05 & $1.92 E-10$ & $-5.22 E-11$ & $1.92 \mathrm{E}-10$ & $5.22 E-11$ & $0.08 \%$ & $0.01 \%$ \\
\hline 505.00 & $2.32 \mathrm{E}-10$ & $5.52 E-11$ & 2.20E-10 & 5.47E-11 & $5.25 \%$ & $0.84 \%$ \\
\hline 509.95 & $2.51 E-10$ & $5.50 \mathrm{E}-11$ & $2.51 E-10$ & $5.50 \mathrm{E}-11$ & $-0.03 \%$ & $-0.03 \%$ \\
\hline 514.90 & $2.86 E-10$ & $5.76 E-11$ & $2.86 E-10$ & $5.76 E-11$ & $0.09 \%$ & $0.03 \%$ \\
\hline 519.85 & $3.24 E-10$ & $6.02 E-11$ & $3.24 \mathrm{E}-10$ & $6.02 \mathrm{E}-11$ & $-0.02 \%$ & $0.00 \%$ \\
\hline 524.80 & $3.66 \mathrm{E}-10$ & $6.29 E-11$ & $3.66 \mathrm{E}-10$ & $6.29 E-11$ & $-0.09 \%$ & $0.04 \%$ \\
\hline 529.75 & 4. $13 E-10$ & $6.56 E-11$ & $4.13 E-10$ & $6.56 \mathrm{E}-11$ & $0.05 \%$ & $0.00 \%$ \\
\hline 534.70 & 2.85E-09 & 6.87E-11. & 2.85E-09 & $6.87 E-11$ & $0.06 \%$ & $-0.01 \%$ \\
\hline 539.65 & 3.09E-09 & $7.16 E-11$ & 3.09E-09 & $7.16 \mathrm{E}-11$ & $-0.05 \%$ & $0.03 \%$ \\
\hline 544.60 & 3.35E-09 & $7.45 E-11$ & 3.35E-09 & $7.45 \mathrm{E}-11$ & $0.04 \%$ & $0.00 \%$ \\
\hline 549.55 & 3.62E-09 & $7.75 E-11$ & 3.62E-09 & 7.75E-11 & $0.01 \%$ & $0.04 \%$ \\
\hline 554.50 & 3.90E-09 & $7.75 \mathrm{E}-11$ & 3.90E-09 & $7.75 \mathrm{E}-11$ & $0.05 \%$ & $0.01 \%$ \\
\hline 559.45 & $4.20 E-09$ & 8.05E-11 & 4.20E-09 & $8.05 E-11$ & $0.07 \%$ & $0.03 \%$ \\
\hline 564.40 & 4.51E-09 & $8.35 E-11$ & 4.51E-09 & 8.35E-11 & $-0.02 \%$ & $-0.02 \%$ \\
\hline 569.35 & 4.84E-09 & 8.66E-11 & 4.84E-09 & 8.66E-11 & $0.01 \%$ & $0.00 \%$ \\
\hline 574.30 & $5.18 \mathrm{E}-09$ & 8.97E-11 & $5.18 E-09$ & 8.97E-11 & $-0.05 \%$ & $-0.04 \%$ \\
\hline 579.25 & 5.54E-09 & $9.29 E-11$ & $5.54 E-09$ & $9.29 E-11$ & $-0.02 \%$ & $-0.02 \%$ \\
\hline 584.20 & 5.92E-09 & $9.61 \mathrm{E}-11$ & 5.92E-09 & $9.61 E-11$ & $0.08 \%$ & $-0.05 \%$ \\
\hline 589.15 & 6.30E-09 & $9.94 \mathrm{E}-11$ & 6.30E-09 & 9.94E-11 & $-0.07 \%$ & $-0.03 \%$ \\
\hline 594.10 & 6.71E-09 & $1.03 \mathrm{E}-10$ & 6.71E-09 & $1.03 E-10$ & $0.02 \%$ & $0.23 \%$ \\
\hline 599.05 & $7.13 \mathrm{E}-09$ & $1.06 \mathrm{E}-10$ & 7.13E-09 & $1.06 E-10$ & $0.02 \%$ & $-0.13 \%$ \\
\hline 604.00 & 7.56E-09 & $1.10 \mathrm{E}-10$ & 7.56E-09 & $1.10 \mathrm{E}-10$ & $-0.06 \%$ & $0.39 \%$ \\
\hline 608.95 & 8.02E-09 & $1.13 \mathrm{E}-10$ & 8.02E-09 & $1.13 E-10$ & $0.06 \%$ & $-0.04 \%$ \\
\hline 613.90 & 8.48E-09 & $1.17 \mathrm{E}-10$ & 8.48E-09 & $1.17 \mathrm{E}-10$ & $-0.03 \%$ & $0.36 \%$ \\
\hline 618.85 & 8.96E-09 & $1.20 \mathrm{E}-10$ & 8.96E-09 & 1.20E-10 & $-0.05 \%$ & $-0.13 \%$ \\
\hline 623.80 & 9.46E-09 & $1.24 E-10$ & 9.46E-09 & $1.24 E-10$ & $-0.02 \%$ & $0.18 \%$ \\
\hline 628.75 & 9.98E-09 & $1.27 E-10$ & 9.98E-09 & $1.27 E-10$ & $0.04 \%$ & $-0.36 \%$ \\
\hline 3.70 & 1.05E-08 & $1.31 E-10$ & $1.05 E-08$ & $1.31 \mathrm{E}-10$ & $-0.04 \%$ & $-0.14 \%$ \\
\hline 638.65 & $1.10 \mathrm{E}-08$ & $1.35 E-10$ & 1.10E-08 & $1.35 E-10$ & $-0.44 \%$ & $0.03 \%$ \\
\hline 643.60 & $1.16 E-08$ & $1.39 \mathrm{E}-10$ & $1.16 \mathrm{E}-08$ & $1.39 E-10$ & $-0.06 \%$ & $0.16 \%$ \\
\hline 648.55 & $1.22 E-08$ & $1.43 \mathrm{E}-10$ & $1.22 E-08$ & $1.43 \mathrm{E}-10$ & $0.15 \%$ & $0.24 \%$ \\
\hline 653.50 & $1.28 \mathrm{E}-08$ & $1.47 E-10$ & $1.28 \mathrm{E}-08$ & $1.47 E-10$ & $0.23 \%$ & $0.28 \%$ \\
\hline 658.45 & $1.34 \mathrm{E}-08$ & $1.51 E-10$ & $1.34 E-08$ & $1.51 E-10$ & $0.19 \%$ & $0.29 \%$ \\
\hline 663.40 & $1.40 \mathrm{E}-08$ & $1.55 E-10$ & $1.40 \mathrm{E}-08$ & $1.55 \mathrm{E}-10$ & $0.04 \%$ & $0.26 \%$ \\
\hline 668.35 & $1.46 \mathrm{E}-08$ & $1.59 E-10$ & $1.46 \mathrm{E}-08$ & $1.59 \mathrm{E}-10$ & $-0.18 \%$ & $0.20 \%$ \\
\hline 673.30 & $1.53 \mathrm{E}-08$ & $1.63 E-10$ & $1.53 E-08$ & $1.63 \mathrm{E}-10$ & $0.17 \%$ & $0.12 \%$ \\
\hline 678.25 & $1.59 E-08$ & $1.67 E-10$ & $1.59 \mathrm{E}-08$ & $1.67 E-10$ & $-0.23 \%$ & $0.00 \%$ \\
\hline 683.20 & 4.81E-09 & $1.71 \mathrm{E}-10$ & 4.81E-09 & $1.71 \mathrm{E}-10$ & $-0.10 \%$ & $-0.13 \%$ \\
\hline 688.15 & $5.11 \mathrm{E}-09$ & $1.76 \mathrm{E}-10$ & $5.11 \mathrm{E}-09$ & $1.76 \mathrm{E}-10$ & $0.08 \%$ & $0.28 \%$ \\
\hline 693.10 & 5.41E-09 & $1.80 \mathrm{E}-10$ & $5.41 E-09$ & $1.80 E-10$ & $0.04 \%$ & $0.09 \%$ \\
\hline 698.05 & 5.72E-09 & $1.84 E-10$ & $5.72 E-09$ & $1.84 E-10$ & $-0.02 \%$ & $-0.13 \%$ \\
\hline 703.00 & $6.04 E-09$ & $1.89 E-10$ & $6.04 E-09$ & $1.89 E-10$ & $-0.08 \%$ & $0.18 \%$ \\
\hline 707.95 & 6.38E-09 & $1.93 E-10$ & $6.38 E-09$ & $1.93 E-10$ & $0.00 \%$ & $-0.08 \%$ \\
\hline
\end{tabular}




\begin{tabular}{|c|c|c|c|c|c|c|}
\hline 712.90 & $6.85 E-09$ & 2.00E-10 & $6.85 E-09$ & $2.00 E-10$ & $-0.06 \%$ & \\
\hline 717.85 & 7.39E-09 & 2.07E-10 & 7.39E-09 & $2.07 E-10$ & $0.06 \%$ & $-0.02 \%$ \\
\hline 722.80 & 7.94E-09 & 2.14E-10 & 7.94E-09 & $2.14 E-10$ & $-0.05 \%$ & $-0.23 \%$ \\
\hline 727.75 & 8.53E-09 & $2.22 E-10$ & 8.53E-09 & 2.22E-10 & $-0.02 \%$ & $-0.07 \%$ \\
\hline 732.70 & $9.15 \mathrm{E}-09$ & $2.30 E-10$ & 9.15E-09 & 2.30E-10 & $0.02 \%$ & $0.00 \%$ \\
\hline 737.65 & 9.79E-09 & $2.38 \mathrm{E}-10$ & 9.79E-09 & $2.38 \mathrm{E}-10$ & $-0.04 \%$ & $-0.01 \%$ \\
\hline 742.60 & $1.05 E-08$ & $2.46 \mathrm{E}-10$ & $1.05 E-08$ & $2.46 \mathrm{E}-10$ & $0.30 \%$ & $-0.10 \%$ \\
\hline 747.55 & $1.12 E-08$ & $2.55 E-10$ & $1.12 \mathrm{E}-08$ & $2.55 E-10$ & $0.23 \%$ & $0.13 \%$ \\
\hline 752.50 & $3.13 E-08$ & $2.63 E=10$ & 3.13E-08, & $2.63 E-10$ & $-0.03 \%$ & $-0.12 \%$ \\
\hline 757.45 & $3.27 E-08$ & $2.72 E-10$ & 3.27E-08 & 2.72E-10 & $-0.08 \%$ & $-0.05 \%$ \\
\hline 762.40 & $3.42 E-08$ & $2.81 E-10$ & 3.42E-08 & $2.81 E-10$ & $0.08 \%$ & $-0.05 \%$ \\
\hline 767.35 & $3.57 E-08$ & $2.90 E-10$ & 3.57E-08 & $2.90 E-10$ & $0.12 \%$ & $-0.13 \%$ \\
\hline 772.30 & $3.72 E-08$ & $3.00 E-10$ & 3.72E-08 & $3.00 E-10$ & $0.07 \%$ & $0.07 \%$ \\
\hline 777.25 & 3.87E-08 & $3.09 E-10$ & 3.87E-08 & 3.09E-10 & $-0.05 \%$ & $-0.14 \%$ \\
\hline 782.20 & 4.03E-08 & $3.19 E-10$ & 4.03E-08 & $3.19 E-10$ & $0.00 \%$ & $-0.08 \%$ \\
\hline 787.15 & 4.19E-08 & $3.29 \mathrm{E}-10$ & 4.19E-08 & $3.29 E-10$ & $-0.02 \%$ & $-0.09 \%$ \\
\hline 792.10 & 4.36E-08 & $3.40 E-10$ & 4.36E-08 & $3.40 \mathrm{E}-10$ & $0.11 \%$ & $0.14 \%$ \\
\hline 797.05 & 4.52E-08 & $3.50 E-10$ & $4.52 E-08$ & $3.50 E-10$ & $-0.05 \%$ & $0.01 \%$ \\
\hline 802.00 & 4.69E-08 & $3.61 E-10$ & 4.69E-08 & $3.61 E-10$ & $-0.05 \%$ & $0.11 \%$ \\
\hline 806.95 & 4.87E-0.8 & $3.71 E-10$ & $4.87 \mathrm{E}-08$ & $3.71 E-10$ & $0.10 \%$ & $-0.12 \%$ \\
\hline 811.90 & $5.04 \mathrm{E}-08$ & $3.82 E-10$ & $5.04 \mathrm{E}-08$ & $3.82 E-10$ & $-0.02 \%$ & $-0.12 \%$ \\
\hline 85 & $5.22 \mathrm{E}-08$ & $3.94 \mathrm{E}-10$ & $=-08$ & $3.94 E-10$ & $0.01 \%$ & $0.07 \%$ \\
\hline 821.80 & $5.40 E-08$ & $4.05 E-10$ & $5.40 E-08$ & $4.05 E-10$ & $-0.02 \%$ & -0.0496 \\
\hline 826.75 & $5.58 \mathrm{E}-08$ & $4.17 \mathrm{E}-10$ & $5.58 E-08$ & $4.17 E-10$ & $-0.09 \%$ & $0.05 \%$ \\
\hline 831.70 & 5.77E-08 & $4.29 E-10$ & 5.77E-08 & 4.29E-10 & $-0.02 \%$ & $0.09 \%$ \\
\hline 836.65 & $5.96 \mathrm{E}-08$ & $4.41 \mathrm{E}-10$ & $5.96 \mathrm{E}-08$ & 4.41E-10 & $0.00 \%$ & $0.08 \%$ \\
\hline & $6.15 \mathrm{E}-08$ & $4.53 E-10$ & 6.15E-0̄8 & $4.53 E-10$ & $-0.02 \%$ & $0.04 \%$ \\
\hline 846.55 & $6.34 \mathrm{E}-08$ & $4: 65 E-10$ & $6.35 E-08$ & $4.65 E-10$ & -0.0 & $-0.05 \%$ \\
\hline 851.50 & $6.54 \mathrm{E}-08$ & $4.78 E-10$ & $6.54 E-08$ & $4.78 E-10$ & $-0.01 \%$ & $0.04 \%$ \\
\hline 856.45 & $6.74 E-08$ & $4.91 E-10$ & $6.74 E-08$ & $4.91 E-10$ & $0.02 \%$ & $0.09 \%$ \\
\hline 861.40 & $6.94 \mathrm{E}-08$ & $5.04 \mathrm{E}-10$ & $E-08$ & $5.04 \mathrm{E}-10$ & $0.02 \%$ & $0.10 \%$ \\
\hline 866. & 7.14 & $5.17 \mathrm{E}-10$ & 7.14 & $5.17 E-10$ & $-0.01 \%$ & $0.07 \%$ \\
\hline 871.30 & 7.34E-08 & $5.30 E-10$ & 7.34E-08 & 5.30E-10 & $-0.07 \%$ & $0.01 \%$ \\
\hline 876.25 & 7.55E-08 & $5.43 E-10$ & $7.55 E-08$ & $5.43 E-10$ & $-0.01 \%$ & $-0.07 \%$ \\
\hline 1.20 & 7.76E-08 & $5.57 E-10$ & 7.76E-08 & $5.57 \mathrm{E}-10$ & $0.02 \%$ & $-0.01 \%$ \\
\hline 88 & 7.97E-08 & $5.71 E-10$ & 7.97E-08 & $5.71 E-10$ & $0.03 \%$ & $0.03 \%$ \\
\hline 891.10 & $8.18 \mathrm{E}-08$ & $5.84 E-10$ & 8.18E-08 & $5.85 E-10$ & $0.02 \%$ & $-0.14 \%$ \\
\hline 896.05 & 8.39E-08 & $5.99 \mathrm{E}-10$ & 8.39E-08 & $5.99 \mathrm{E}-10$ & $-0.01 \%$ & $0.02 \%$ \\
\hline .00 & 8.60E-08 & $6.13 E-10$ & 8.60E-08 & $6.13 E-10$ & $-0.05 \%$ & $-0.03 \%$ \\
\hline & 8.82E-08 & $6.28 E-10$ & 8.82 & $6.28 \mathrm{E}-10$ & $0.01 \%$ & $0.06 \%$ \\
\hline & $9.04 E-08$ & $6.42 E-10$ & $9.04 E-08$ & $6.42 E-10$ & $0.05 \%$ & $-0.03 \%$ \\
\hline 915.85 & $9.25 E-08$ & $6.57 \mathrm{E}-10$ & $9.25 E-08$ & $6.57 E-10$ & $-0.03 \%$ & $0.02 \%$ \\
\hline 920.80 & $9.47 E-08$ & $6.72 \mathrm{E}-10$ & 9.47E-08 & $6.72 E-10$ & $-0.02 \%$ & $0.04 \%$ \\
\hline & $9.69 \mathrm{E}-08$ & $6.87 E-10$ & 9.69E-08 & $6.87 E-10$ & $-0.01 \%$ & $0.04 \%$ \\
\hline & $9.91 E-08$ & $7.02 E-10$ & 9.91E-08 & $7.02 E-10$ & $-0.01 \%$ & $0.03 \%$ \\
\hline 935.65 & $1.01 E-07$ & $7.17 E-10$ & $1.01 \mathrm{E}-07$ & $7.17 \mathrm{E}-10$ & $=0.32 \%$ & $-0.01 \%$ \\
\hline 940.60 & $1.04 E-07$ & $7.32 E-10$ & $1.04 \mathrm{E}-07$ & 7.32E-10 & $0.44 \%$ & $-0.06 \%$ \\
\hline & $1.06 \mathrm{E}-07$ & $7.48 E-1$ & $1.06 \mathrm{E}-07$ & $7.48 \mathrm{E}-10$ & $0.22 \%$ & $0.01 \%$ \\
\hline & $1.08 \mathrm{E}-07$ & $7.63 E-10$ & $1.08 \mathrm{E}-07$ & $7.63 E-10$ & $0.00 \%$ & $-0.06 \%$ \\
\hline
\end{tabular}




$\begin{array}{rrrrrrr}955.45 & 1.10 \mathrm{E}-07 & 7.79 \mathrm{E}-10 & 1.10 \mathrm{E}-07 & 7.79 \mathrm{E}-10 & -0.22 \% & -0.02 \% \\ 960.40 & 1.12 \mathrm{E}-07 & 7.95 \mathrm{E}-10 & 1.12 \mathrm{E}-07 & 7.95 \mathrm{E}-10 & -0.43 \% & 0.00 \% \\ 965.35 & 1.15 \mathrm{E}-07 & 8.11 \mathrm{E}-10 & 1.15 \mathrm{E}-07 & 8.11 \mathrm{E}-10 & 0.24 \% & 0.01 \% \\ 970.30 & 1.17 \mathrm{E}-07 & 8.27 \mathrm{E}-10 & 1.17 \mathrm{E}-07 & 8.27 \mathrm{E}-10 & 0.02 \% & 0.01 \% \\ 975.25 & 1.19 \mathrm{E}-07 & 8.43 \mathrm{E}-10 & 1.19 \mathrm{E}-07 & 8.43 \mathrm{E}-10 & -0.19 \% & 0.00 \% \\ 980.20 & 1.21 \mathrm{E}-07 & 8.59 \mathrm{E}-10 & 1.21 \mathrm{E}-07 & 8.59 \mathrm{E}-10 & -0.39 \% & -0.03 \% \\ 985.15 & 1.24 \mathrm{E}-07 & 8.75 \mathrm{E}-10 & 1.24 \mathrm{E}-07 & 8.75 \mathrm{E}-10 & 0.22 \% & -0.06 \% \\ 990.10 & 1.26 \mathrm{E}-07 & 8.92 \mathrm{E}-10 & 1.26 \mathrm{E}-07 & 8.92 \mathrm{E}-10 & 0.02 \% & 0.02 \% \\ 995.05 & 1.28 \mathrm{E}-07 & 9.08 \mathrm{E}-10 & 1.28 \mathrm{E}-07 & 9.08 \mathrm{E}-10 & -0.18 \% & -0.03 \%\end{array}$


Table A4. Test Cases 3 through 8

TEST CASE \# 3

\begin{tabular}{cccc}
$\begin{array}{c}\text { Downwind } \\
\text { Distance } \\
(\mathrm{m})\end{array}$ & $\begin{array}{c}\text { VENTSAR } \\
\text { X/Q } \\
\left(\mathrm{s} / \mathrm{m}^{\star *} 3\right)\end{array}$ & $\begin{array}{c}\text { VENTSAR XL } \\
\text { X/Q } \\
\left(\mathrm{s} / \mathrm{m}^{\star *} 3\right)\end{array}$ & $\begin{array}{c}\% \text { Diff } \\
\text { X/Q } \\
(\%)\end{array}$ \\
\hline 10 & $3.66 \mathrm{E}-17$ & $3.66 \mathrm{E}-17$ & $0.00 \%$ \\
109 & $8.69 \mathrm{E}-04$ & $8.69 \mathrm{E}-04$ & $0.00 \%$ \\
208 & $3.93 \mathrm{E}-04$ & $3.93 \mathrm{E}-04$ & $0.00 \%$ \\
307, & $2.11 \mathrm{E}-04$ & $2.11 \mathrm{E}-04$ & $0.00 \%$ \\
406 & $1.35 \mathrm{E}-04$ & $1.35 \mathrm{E}-04$ & $0.00 \%$ \\
505 & $9.51 \mathrm{E}-05$ & $9.51 \mathrm{E}-05$ & $0.00 \%$ \\
604 & $7.18 \mathrm{E}-05$ & $7.18 \mathrm{E}-05$ & $0.00 \%$ \\
703 & $5.67 \mathrm{E}-05$ & $5.67 \mathrm{E}-05$ & $0.00 \%$ \\
802 & $4.63 \mathrm{E}-0.5$ & $4.63 \mathrm{E}-05$ & $0.00 \%$ \\
901 & $3.88 \mathrm{E}-05$ & $3.88 \mathrm{E}-05$ & $0.00 \%$
\end{tabular}

TEST CASE \# 4

\begin{tabular}{cccc}
$\begin{array}{c}\text { Downwind } \\
\text { Distance } \\
(\mathrm{m})\end{array}$ & $\begin{array}{c}\text { VENTSAR } \\
\text { X/Q } \\
\left(\mathrm{s} / \mathrm{m}^{\star *}\right)\end{array}$ & $\begin{array}{c}\text { VENTSAR XL } \\
\text { X/Q } \\
\left(\mathrm{s} / \mathrm{m}^{\star *} 3\right)\end{array}$ & $\begin{array}{c}\text { \% Diff } \\
\text { X/Q } \\
(\%)\end{array}$ \\
\hline 10 & $0.00 \mathrm{E}+00$ & $0.00 \mathrm{E}+00$ & \\
109 & $0.00 \mathrm{E}+00$ & $0.00 \mathrm{E}+00$ & \\
208 & $0.00 \mathrm{E}+00$ & $9.83 \mathrm{E}-300$ & \\
307 & $0.00 \mathrm{E}+00$ & $3.82 \mathrm{E}-147$ & \\
406 & $0.00 \mathrm{E}+00$ & $3.19 \mathrm{E}-90$ & \\
505 & $1.14 \mathrm{E}-62$ & $1.13 \mathrm{E}-62$ & $0.47 \%$ \\
604 & $3.73 \mathrm{E}-47$ & $3.72 \mathrm{E}-47$ & $0.31 \%$ \\
703 & $1.67 \mathrm{E}-37$ & $1.66 \mathrm{E}-37$ & $0.41 \%$ \\
802 & $4.59 \mathrm{E}-31$ & $4.58 \mathrm{E}-31$ & $0.18 \%$ \\
901 & $1.55 \mathrm{E}-26$ & $1.55 \mathrm{E}-26$ & $0.06 \%$
\end{tabular}

TEST CASE \# 5

\begin{tabular}{cccc}
$\begin{array}{c}\text { Downwind } \\
\text { Distance } \\
(\mathrm{m})\end{array}$ & $\begin{array}{c}\text { VENTSAR } \\
\text { X/Q } \\
\left(\mathrm{s} / \mathrm{m}^{\star *} 3\right)\end{array}$ & $\begin{array}{c}\text { VENTSAR XL } \\
\text { X/Q } \\
\left(\mathrm{s} / \mathrm{m}^{\star *} 3\right)\end{array}$ & $\begin{array}{c}\text { \% Diff } \\
\text { X/Q } \\
(\%)\end{array}$ \\
\hline 10 & $0.00 \mathrm{E}+00$ & $0.00 \mathrm{E}+00$ & \\
109 & $1.76 \mathrm{E}-12$ & $1.76 \mathrm{E}-12$ & $0.00 \%$ \\
208 & $2.01 \mathrm{E}-07$ & $2.01 \mathrm{E}-07$ & $0.00 \%$ \\
307 & $6.43 \mathrm{E}-07$ & $6.43 \mathrm{E}-07$ & $0.00 \%$ \\
406 & $1.86 \mathrm{E}-06$ & $1.86 \mathrm{E}-06$ & $0.00 \%$ \\
505 & $2.62 \mathrm{E}-06$ & $2.62 \mathrm{E}-06$ & $0.00 \%$ \\
604 & $2.84 \mathrm{E}-06$ & $2.84 \mathrm{E}-06$ & $0.00 \%$ \\
703 & $2.76 \mathrm{E}-06$ & $2.76 \mathrm{E}-06$ & $0.00 \%$ \\
802 & $2.56 \mathrm{E}-06$ & $2.56 \mathrm{E}-06$ & $0.00 \%$ \\
901 & $2.32 \mathrm{E}-06$ & $-2.32 \mathrm{E}-06$ & $0.00 \%$
\end{tabular}


TEST CASE \# 6

\begin{tabular}{|c|c|c|c|c|c|c|}
\hline $\begin{array}{c}\text { Downwind } \\
\text { Distance } \\
(\mathrm{m}) \\
\end{array}$ & $\begin{array}{l}\text { VENTSAR } \\
99.5 \% \times / Q \\
\left(\mathrm{~s} / \mathrm{m}^{\star *} 3\right) \\
\end{array}$ & $\begin{array}{l}\text { VENTSAR } \\
\text { Annual } X / Q \\
\left(\mathrm{~s} / \mathrm{m}^{\star *}\right)\end{array}$ & $\begin{array}{l}\text { VENTSAR XL } \\
99.5 \% \times / Q \\
\left(\mathrm{~s} / \mathrm{m}^{\star \star 3}\right)\end{array}$ & $\begin{array}{l}\text { VENTSAR XL } \\
\text { Annual X/Q } \\
\left(\mathrm{s} / \mathrm{m}^{\star \star 3}\right)\end{array}$ & $\begin{array}{c}\% \text { Diff } \\
99.5 \% \\
X / Q \\
(\%)\end{array}$ & $\begin{array}{c}\% \text { Diff } \\
\text { Annual } \\
X / Q \\
(\%)\end{array}$ \\
\hline 10 & $0.00 E+00$ & $0.00 E+00$ & $3.46 E-138$ & $2.74 E-140$ & & \\
\hline 109 & $1.40 \mathrm{E}-05$ & $1.11 t$ & 1.40 & $=-07$ & $0.00 \%$ & $0.00 \%$ \\
\hline 208 & $2.00 \mathrm{E}-05$ & $2.63 \mathrm{E}$ & 2.0 & -07 & $0.00 \%$ & $0.00 \%$ \\
\hline 307 & $1.48 E-05$ & 2.431 & $1.48 \mathrm{E}-05$ & -07 & $0.00 \%$ & $0.00 \%$ \\
\hline 406 & $1.29 E-05$ & 2.14 & $1.29 E-05$ & $=-07$ & $0.00 \%$ & $0.00 \%$ \\
\hline 505 & $1.06 E$ & 1.9 & $1.06 \mathrm{E}-05$ & -07 & $0.00 \%$ & $0.00 \%$ \\
\hline 604 & $9.21 E-06$ & $1.73 E-07$ & $9.21 E-06$ & $1.73 E-07$ & $0.00 \%$ & $0.00 \%$ \\
\hline & 8.43E-06 & $1.60 \mathrm{E}-07$ & 8.43E-06 & 1.60E-07 & $0.00 \%$ & $0.00 \%$ \\
\hline & & $1.50 \mathrm{E}-07$ & 8.39E-06 & $1.50 \mathrm{E}-07$ & $0.00 \%$ & $0.00 \%$ \\
\hline 901 & 7.30E-06 & $1.42 \mathrm{E}-07$ & $7.30 \mathrm{E}-06$ & $1.42 \mathrm{E}-07$ & $0.00 \%$ & $0.00 \%$ \\
\hline
\end{tabular}

TEST CASE \# 7

\begin{tabular}{|c|c|c|c|c|c|c|}
\hline $\begin{array}{c}\text { Downwind } \\
\text { Distance } \\
(m) \\
\end{array}$ & $\begin{array}{l}\text { VENTSAR } \\
99.5 \% \times / Q \\
\left(\mathrm{~s} / \mathrm{m}^{\star} 3\right)\end{array}$ & $\begin{array}{l}\text { VENTSAR } \\
\text { Annual } X / Q \\
\left(\mathrm{~s} / \mathrm{m}^{\star * 3)}\right.\end{array}$ & $\begin{array}{l}\text { VENTSAR XL } \\
99.5 \% \times / Q \\
\left(\mathrm{~s} / \mathrm{m}^{\star *}\right)\end{array}$ & $\begin{array}{l}\text { VENTSAR XL } \\
\text { Annual } X / Q \\
\left(s / m^{\star *}\right)\end{array}$ & $\begin{array}{c}\% \text { Diff } \\
99.5 \% \\
\text { XQ } \\
(\%)\end{array}$ & $\begin{array}{c}\% \text { Diff } \\
\text { Annual } \\
X / Q \\
(\%)\end{array}$ \\
\hline 10 & $0.00 E+00$ & $0.00 E+00$ & $0.00 E+00$ & $0.00 E+00$ & & \\
\hline 109 & $0.00 E+00$ & 2.86 & $1.05 E-96$ & 2.85E-28 & & $0.22 \%$ \\
\hline 208 & $6.78 \mathrm{E}-45$ & 1.56 & 6.7 & $1.56 E-16$ & $0.00 \%$ & \\
\hline 307 & $5.89 E-32$ & 1.93 & $E-32$ & 1.93 & $0.01 \%$ & $5 \%$ \\
\hline 406 & $1.76 \mathrm{E}-27$ & 2.4 & $E-27$ & $2.40 E-12$ & $0.09 \%$ & -0.1 \\
\hline 505 & 2.30E-17 & $7.98 E-12$ & 2.30E-17 & $7.98 E-12$ & $0.02 \%$ & $0.01 \%$ \\
\hline & $1.27 E-14$ & 1.61 & $7 E-14$ & $1.61 \mathrm{E}-11$ & $0.27 \%$ & $0.07 \%$ \\
\hline 70 & $6.47 E-13$ & 2.61 & $7 E-13$ & $2.61 E-11$ & $0.04 \%$ & $0.08 \%$ \\
\hline 802 & $1.09 E-11$ & $4.03 \mathrm{E}-11$ & $1.09 \mathrm{E}-11$ & $4.03 E-11$ & $-0.40 \%$ & $-0.08 \%$ \\
\hline 901 & $1.01 E-10$ & $6.40 \mathrm{E}-11$ & $1.01 E-10$ & $6.40 \mathrm{E}-11$ & $-0.37 \%$ & 0.089 \\
\hline
\end{tabular}

TEST CASE \# 8

\begin{tabular}{cccc}
$\begin{array}{c}\text { Downwind } \\
\text { Distance } \\
(\mathrm{m})\end{array}$ & $\begin{array}{c}\text { VENTSAR } \\
99.5 \% \times / \mathrm{Q} \\
\left(\mathrm{s} / \mathrm{m}^{\star *}\right)\end{array}$ & $\begin{array}{c}\text { VENTSAR XL } \\
99.5 \% \times / \mathrm{Q} \\
\left(\mathrm{s} / \mathrm{m}^{\star *} 3\right)\end{array}$ & $\begin{array}{c}\text { \% Diff } \\
99.5 \% \times / \mathrm{Q} \\
(\%)\end{array}$ \\
\hline 10 & $1.17 \mathrm{E}-02$ & $1.17 \mathrm{E}-02$ & $-0.37 \%$ \\
109 & $1.18 \mathrm{E}-04$ & $1.18 \mathrm{E}-04$ & $0.04 \%$ \\
208 & $3.48 \mathrm{E}-05$ & $3.48 \mathrm{E}-05$ & $0.08 \%$ \\
307 & $1.68 \mathrm{E}-05$ & $1.68 \mathrm{E}-05$ & $0.04 \%$ \\
406 & $1.00 \mathrm{E}-05$ & $1.00 \mathrm{E}-05$ & $0.01 \%$ \\
505 & $6.69 \mathrm{E}-06$ & $6.69 \mathrm{E}-06$ & $0.03 \%$ \\
604 & $4.82 \mathrm{E}-06$ & $4.82 \mathrm{E}-06$ & $0.07 \%$ \\
703 & $3.65 \mathrm{E}-06$ & $3.65 \mathrm{E}-06$ & $-0.02 \%$ \\
802 & $2.87 \mathrm{E}-06$ & $2.87 \mathrm{E}-06$ & $-0.10 \%$ \\
901 & $2.33 \mathrm{E}-06$ & $2.33 \mathrm{E}-06$ & $0.14 \%$
\end{tabular}


APPENDIX B ADDITIONAL TEST CASE DEMONSTRATION 


\section{APPENDIX B. ADDITIONAL TEST CASE DEMONSTRATION}

Four additional test cases were created to ensure proper application of methodologies. Parameters for the additional test cases are shown in Table B1. Results for test cases 9-12 are shown in Table B2 for selected downwind distances. Differences are less than $0.01 \%$ for all receptor distances.

Table B1. Test Cases Parameters

\begin{tabular}{|c|c|c|c|c|}
\hline Parameter* & Case 9 & Case 10 & Case 11 & Case 12 \\
\hline Consider Plúme Rise & NO & NO & YES & NO \\
\hline Area of Release & $\#$ & $\#$ & $\mathrm{C}$ & A \\
\hline Building Height & 10 & 10 & 40 & 10 \\
\hline Building Width & 100 & 100 & 30 & 10 \\
\hline Building Length & 100 & 100 & 100 & 10 \\
\hline Penthouse Height & 5 & 5 & 5 & 5 \\
\hline Penthouse Width & 90 & 90 & 10 & 5 \\
\hline Pențhouse Length & 90 & 90 & 30 & 5 \\
\hline Bldg. to Penthouse & 5 & 5 & 70 & 1 \\
\hline Min. Vent to Receptor & 10 & 10 & 10 & 1 \\
\hline Max. Vent to Receptor & 510 & 510 & 1010 & 101 \\
\hline Number of Increments & 200 & 200 & 200 & 200 \\
\hline Compass Sector & $S$ & $S$ & SSE & $\mathrm{E}$ \\
\hline Vent to Roof Edge & -10 & -10 & 70 & 20 \\
\hline Vent Height & 10 & 10 & 0 & 0 . \\
\hline Radioactive Release? & YES & YES & NO & YES \\
\hline Release Rate (Ci/min) & 1 & 1 & - & 1 \\
\hline Pollutant Mole Fraction & 0.000001 & 0.000001 & - & 0.000001 \\
\hline Vent-Gas Flow Rate $\left(m^{\wedge} 3 / s\right)$ & 500 & 500 & 1000 & 500 \\
\hline Met. Averaging? & YES & NO & YES & NO \\
\hline Probability Level & 0.005 & - & 0.005 & - \\
\hline Wind Speed $(\mathrm{m} / \mathrm{s})$ & - & 4.5 & - & 3 \\
\hline Stability Class & - & D & - & $B$ \\
\hline Vent Diameter & 1 & 1 & 1 & 1 \\
\hline Vent-Gas Molecular Weight & 29 & 29 & 190 & 30 \\
\hline Vent-Gas Temp(C) & 30 & 30 & 100 & 20 \\
\hline Ambient Air Temp(C) & 30 & 30 & 20 & 20 \\
\hline
\end{tabular}

\# Release Coordinates at center of site: E58000; N 62000 
Table B2. Comparison of VENTSAR XI and VENTSAR for Additional Test Cases

\section{TEST CASE \# 9}

\begin{tabular}{|c|c|c|c|c|c|c|}
\hline $\begin{array}{c}\text { Downwind } \\
\text { Distance } \\
\text { (m) }\end{array}$ & $\begin{array}{r}\text { VENTSAR } \\
99.5 \% \times / Q \\
\left(\mathrm{~s} / \mathrm{m}^{\star *} 3\right)\end{array}$ & $\begin{array}{l}\text { VENTSAR } \\
\text { Annual } X Q \\
\left(s / m^{\star *} 3\right)\end{array}$ & $\begin{array}{l}\text { VENTSAR XL } \\
99.5 \% \times / Q \\
\left(\mathrm{~s} / \mathrm{m}^{\star \star 3}\right)\end{array}$ & $\begin{array}{l}\text { VENTSAR XL } \\
\text { Annual } X / Q \\
\left(s / m^{\star *} 3\right)\end{array}$ & $\begin{array}{l}\text { \% Diff } \\
99.5 \% \\
X / Q \\
(\%)\end{array}$ & $\begin{array}{c}\% \text { Diff } \\
\text { Annual } \\
X / Q \\
(\%)\end{array}$ \\
\hline 10 & $9.14 \mathrm{E}-18$ & $9.66 \mathrm{E}-10$ & $9.14 E-08$ & $9.66 E-10$ & & $0.00 \%$ \\
\hline 60 & $8.42 E-04$ & 2.45E-05 & 8.42E-04 & 2.45E-05 & $0.00 \%$ & $0.00 \%$ \\
\hline 110 & 2.38E-04 & 4.59E-06 & 2.38E-04. & $4.59 E-06$ & $0.00 \%$ & $0.00 \%$ \\
\hline 160 & 8.38E-05 & $1.84 \mathrm{E}-06$ & $8.38 E-05$ & $1.84 E-06$ & $0.00 \%$ & $0.00 \%$ \\
\hline 210 & 7.61E-05 & $1.52 \mathrm{E}-06$ & $7.61 E-05$ & 1.52E-06 & $0.00 \%$ & $0.00 \%$ \\
\hline 260 & 5.61E-05 & $1.23 \mathrm{E}-06$ & $5.61 E-05$ & $1.23 \mathrm{E}-06$ & $0.00 \%$ & $0.00 \%$ \\
\hline 310 & $6.12 E-05$ & $1.00 \mathrm{E}-06$ & $6.12 E-05$ & $1.00 \mathrm{E}-06$ & $0.00 \%$ & $0.00 \%$ \\
\hline 360 & 4.97E-05 & 8.36E-07 & 4.97E-05 & 8.36E-07 & $0.00 \%$ & $0.00 \%$ \\
\hline 410 & $4.08 \mathrm{E}-05$ & $7.15 \mathrm{E}-07$. & $4.08 E-05$ & $7.15 \mathrm{E}-07$ & $0.00 \%$ & $0.00 \%$ \\
\hline 460 & $3.65 \mathrm{E}-05$ & 6.21E-07 & $3.65 E-05$ & $6.21 \mathrm{E}-07$ & $0.00 \%$ & $0.00 \%$ \\
\hline
\end{tabular}

TEST CASE \# 10

\begin{tabular}{cccc}
$\begin{array}{c}\text { Downwind } \\
\text { Distance } \\
(\mathrm{m})\end{array}$ & $\begin{array}{c}\text { VENTSAR } \\
\text { X/Q } \\
\left(\mathrm{s} / \mathrm{m}^{\star *} 3\right)\end{array}$ & $\begin{array}{c}\text { VENTSAR XL } \\
\mathrm{X} / \mathrm{Q} \\
\left(\mathrm{s} / \mathrm{m}^{\star *} 3\right)\end{array}$ & $\begin{array}{c}\% \text { Diff } \\
\times / Q \\
(\%)\end{array}$ \\
\hline 10 & $3.17 \mathrm{E}-63$ & $3.17 \mathrm{E}-63$ & $0.00 \%$ \\
60 & $9.39 \mathrm{E}-04$ & $9.39 \mathrm{E}-04$ & $0.00 \%$ \\
110 & $1.60 \mathrm{E}-04$ & $1.60 \mathrm{E}-04$ & $0.00 \%$ \\
160 & $2.87 \mathrm{E}-05$ & $2.87 \mathrm{E}-05$ & $0.00 \%$ \\
210 & $4.13 \mathrm{E}-05$ & $4.13 \mathrm{E}-05$ & $0.00 \%$ \\
260 & $4.98 \mathrm{E}-05$ & $4.98 \mathrm{E}-05$ & $-0.00 \%$ \\
310 & $5.20 \mathrm{E}-05$ & $5.20 \mathrm{E}-05$ & $0.00 \%$ \\
360 & $4.99 \mathrm{E}-05$ & $4.99 \mathrm{E}-05$ & $0.00 \%$ \\
410 & $4.60 \mathrm{E}-05$ & $4.60 \mathrm{E}-05$ & $0.00 \%$ \\
460 & $4.15 \mathrm{E}-05$ & $4.15 \mathrm{E}-05$ & $0.00 \%$
\end{tabular}


Table B2. Cont. Comparison of VENTSAR XL and VENTSAR for Additional Test Cases

\section{TEST CASE \#11}

Downwind VENTSAR VENTSAR VENTSAR XL VENTSAR XL \% Diff \% DIff

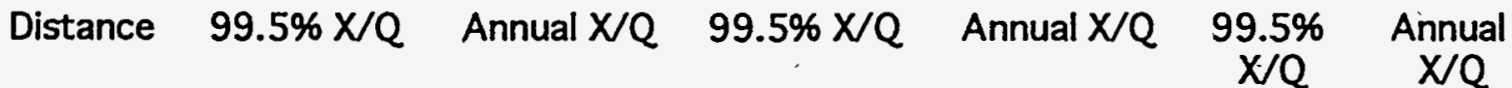

\begin{tabular}{ccccccc}
$(\mathrm{m})$ & $\left(\mathrm{s} / \mathrm{m}^{\star *} 3\right)$ & $\left(\mathrm{s} / \mathrm{m}^{\star *} 3\right)$ & $\left(\mathrm{s} / \mathrm{m}^{\star *} 3\right)$ & $\left(\mathrm{s} / \mathrm{m}^{\star *} 3\right)$ & $(\%)$ & $(\%)$ \\
\hline 10 & $0.00 \mathrm{E}+00$ & $0.00 \mathrm{E}+00$ & $0.00 \mathrm{E}+00$ & $1.39 \mathrm{E}-116$ & $\star$ & $\star \star$ \\
110 & $0.00 \mathrm{E}+00$ & $1.64 \mathrm{E}-31$ & $4.29 \mathrm{E}-96$ & $1.64 \mathrm{E}-31$ & $\star \star$ & $0.00 \%$ \\
210 & $2.19 \mathrm{E}-42$ & $1.08 \mathrm{E}-17$ & $2.19 \mathrm{E}-42$ & $1.08 \mathrm{E}-17$ & $0.00 \%$ & $0.00 \%$ \\
310 & $2.31 \mathrm{E}-25$ & $2.68 \mathrm{E}-14$ & $2.31 \mathrm{E}-25$ & $2.68 \mathrm{E}-14$ & $0.00 \%$ & $0.00 \%$ \\
410 & $1.21 \mathrm{E}-18$ & $4.89 \mathrm{E}-13$ & $1.21 \mathrm{E}-18$ & $4.89 \mathrm{E}-13$ & $0.00 \%$ & $0.00 \%$ \\
510 & $2.94 \mathrm{E}-15$ & $1.90 \mathrm{E}-12$ & $2.94 \mathrm{E}-15$ & $1.90 \mathrm{E}-12$ & $0.00 \%$ & $0.00 \%$ \\
610 & $2.72 \mathrm{E}-13$ & $3.97 \mathrm{E}-12$ & $2.72 \mathrm{E}-13$ & $3.97 \mathrm{E}-12$ & $0.00 \%$ & $0.00 \%$ \\
710 & $4.82 \mathrm{E}-12$ & $6.34 \mathrm{E}-12$ & $4.82 \mathrm{E}-12$ & $6.34 \mathrm{E}-12$ & $0.00 \%$ & $0.00 \%$ \\
810 & $3.38 \mathrm{E}-11$ & $9.16 \mathrm{E}-12$ & $3.38 \mathrm{E}-11$ & $9.16 \mathrm{E}-12$ & $0.00 \%$ & $0.00 \%$ \\
910 & $1.35 \mathrm{E}-10$ & $1.29 \mathrm{E}-11$ & $1.35 \mathrm{E}-10$ & $1.29 \mathrm{E}-11$ & $0.00 \%$ & $0.00 \%$
\end{tabular}

TEST CASE \# 12

\begin{tabular}{cccc}
$\begin{array}{c}\text { Downwind } \\
\text { Distance } \\
(\mathrm{m})\end{array}$ & $\begin{array}{c}\text { VENTSAR } \\
\text { X/Q } \\
\left(\mathrm{s} / \mathrm{m}^{\star *} 3\right)\end{array}$ & $\begin{array}{c}\text { VENTSAR XL } \\
\text { X/Q } \\
\left(\mathrm{s} / \mathrm{m}^{\star *} 3\right)\end{array}$ & $\begin{array}{c}\% \text { Diff } \\
\text { X/Q } \\
(\%)\end{array}$ \\
\hline 10 & $2.35 \mathrm{E}-03$ & $2.35 \mathrm{E}-03$ & $0.00 \%$ \\
20 & $1.57 \mathrm{E}-03$ & $1.57 \mathrm{E}-03$ & $0.00 \%$ \\
30 & $1.10 \mathrm{E}-03$ & $1.10 \mathrm{E}-03$ & $0.00 \%$ \\
40 & $8.05 \mathrm{E}-04$ & $8.05 \mathrm{E}-04$ & $0.00 \%$ \\
50 & $6.09 \mathrm{E}-04$ & $6.09 \mathrm{E}-04$ & $0.00 \%$ \\
60 & $4.75 \mathrm{E}-04$ & $4.75 \mathrm{E}-04$ & $0.00 \%$ \\
70 & $3.81 \mathrm{E}-04$ & $3.81 \mathrm{E}-04$ & $0.00 \%$ \\
80 & $3.11 \mathrm{E}-04$ & $3.11 \mathrm{E}-04$ & $0.00 \%$ \\
90 & $2.59 \mathrm{E}-04$ & $2.59 \mathrm{E}-04$ & $0.00 \%$ \\
100 & $2.19 \mathrm{E}-04$ & $2.19 \mathrm{E}-04$ & $0.00 \%$
\end{tabular}

**Value determined in VENTSAR is below threshold value for printout. 


\section{APPENDIX C. HAND CALCULATIONS}

Independent hand calculations were performed to demonstrate that VENTSAR XL was correctly applying the methodologies previously discussed.

\subsection{Plume Rise Options}

For a downwind distance of $10 \mathrm{~m}$, the following calculations were performed to verify plume rise methodologies using the parameters shown in Table 5.

Buoyancy Effects

$$
\begin{aligned}
& D R H O=\frac{M W_{a} T_{e}-M W_{e} T_{a}}{2 M W_{a} T_{c}} \\
& M W_{c}=M F C T \times M W_{c}+(1-M F C T) M W_{a} \\
& M W_{c}=1.8 \mathrm{E}-06 \times 78.12+(1-1.8 \mathrm{E}-06) 28.9 \\
& M W_{c}=28.90
\end{aligned}
$$

Using all other known parameters the following is determined.

$D R H O=0.0319$

The buoyancy flux, $F_{0}$, is then calculated using the following equation:

$F_{o}=2.0 \times G \times D R H O \times C M S$

$$
F_{o}=2.0 \times 9.8\left(\frac{m}{s^{2}}\right) \times 0.0319 \times 50\left(\frac{m^{3}}{s}\right)=31.26 \mathrm{~m}^{4} / \mathrm{s}^{3}
$$

Since the buoyancy flux is less than 55.0, XSTR is calculated as follows:

$$
X S T R=49.0 \times F_{o}^{0.625}=49.0 \times 31.26^{0.625}=421.3 \mathrm{~m}
$$

Since the weather conditions are neutral (D stability) the value of the stability parameter, $\mathrm{S}$, is one. Increase in release height due to buoyancy is:

$$
\Delta h_{B}=1.6 \frac{F_{o}^{1 / 3} X^{2 / 3}}{U}=1.6 \frac{31.26^{1 / 3} 10^{2 / 3}}{6}=3.90 \mathrm{~m}
$$

Momentum Effects

The velocity of the plume, $V_{e}$, is calculated as follows: 
WESTINGHOUSE SAVANNAH RIVER COMPANY

WSRC-RP-96-228

$$
\begin{aligned}
& \mathrm{V}_{\mathrm{c}}=\mathrm{CMS} / \text { AREA } \\
& \mathrm{V}_{\mathrm{e}}=50 \frac{\mathrm{m}^{3}}{\mathrm{~s}} /\left[\pi(0.5 \mathrm{~m})^{2}\right]=63.66 \frac{\mathrm{m}^{3}}{\mathrm{~s}} \\
& \mathrm{~B} 1=\frac{0.75 \times \pi}{\left(0.4+1.2 \times \mathrm{U} / \mathrm{V}_{\mathrm{e}}\right)^{2}}=\frac{0.75 \times \pi}{\left(0.4+1.2 \times 6.0 \frac{\mathrm{m}}{\mathrm{s}} / 63.66 \frac{\mathrm{m}^{3}}{\mathrm{~s}}\right)^{2}}=8.95 \\
& M_{o}=\left[\frac{M W_{e} T_{a}}{M W_{a} T_{e}}\right]^{0.5}=\left[\frac{28.9 \times 293}{28.9 \times 313}\right]^{0.5}=0.97 \\
& D H M O M=\frac{D \times V_{e} M_{o}}{U}=\frac{1 \mathrm{~m} \times 63.66 \frac{\mathrm{m}}{\mathrm{s}} \times 0.97}{6 \frac{\mathrm{m}}{\mathrm{s}}}=10.29
\end{aligned}
$$

Using the above parameters, XTEST can be calculated as follows:

$$
X T E S T=\frac{27.0 * D H M O M}{B 1}=\frac{27.0 * 10.29}{8.95}=31.04 \mathrm{~m}
$$

Since X is less than XTEST

$$
\Delta h_{m}=\left(B 1 * X * D H M O M^{2}\right)^{1 / 3}=\left(8.95 * 10 * 10.29^{2}\right)^{1 / 3}=21.15 \mathrm{~m} .
$$

There is no downwash since $\mathrm{V}_{\mathrm{e}} / \mathrm{U}>1.5$.

The effective change in plume height is

$$
\begin{aligned}
& h(x)=h_{s}-\Delta h_{D}+\Delta h_{B}(x)+\Delta h_{M A}(x) \\
& h(x)=20.0-0.00+3.90+21.15=44.99 \mathrm{~m}
\end{aligned}
$$

The concentration is calculated as follows:

$$
\frac{\chi}{Q}=\frac{1}{2 \pi \sigma_{y} \sigma_{z} U_{S}}\left[e^{-\left(\frac{\left(z-h_{s}\right)^{2}}{2 \sigma_{z}^{2}}\right)}+e^{-\left(\frac{\left(z+h_{c}\right)^{2}}{2 \sigma_{z}^{2}}\right)}\right]
$$

46 
For $\mathrm{D}$ stability $10 \mathrm{~m}$ downwind of release location

$$
\begin{aligned}
& \sigma_{\mathrm{y}}=\frac{\sigma_{\theta} \mathrm{x}}{1+0.031(\mathrm{x})^{0.46}} \quad \sigma_{\mathrm{z}}=0.06 \mathrm{x}(1+0.0015 \mathrm{x})^{-0.5} \\
& \sigma_{\mathrm{y}}=\frac{0.218 * 10 \mathrm{~m}}{1+0.031(10)^{0.46}} \quad \sigma_{\mathrm{z}}=0.06 * 10 \mathrm{~m}(1+0.0015 * 10)-0.5 \\
& \sigma_{\mathrm{y}}=2.001 \mathrm{~m} \quad \sigma_{\mathrm{z}}=0.596 \mathrm{~m} \\
& \frac{\chi}{\mathrm{Q}}=\frac{\mathrm{e}^{-0.5(44.99 / 0.596)^{2}}+\mathrm{e}^{-0.5(44.99 / 0.596)^{2}}}{2^{*} 3.14^{*} 2.001 \mathrm{~m}^{*} 0.596 \mathrm{~m}^{*} 6 \mathrm{~m} / \mathrm{s}}=0.0 \mathrm{E}+00 \mathrm{~s} / \mathrm{m}^{3}
\end{aligned}
$$

The following hand calculation is for a downwind distance of $\mathrm{X}=200 \mathrm{~m}$.

Using the same constants as above and since $\mathrm{X}<\mathrm{XSTR}$

$$
\Delta h_{B}=1.6 \frac{F_{0}^{1 / 3} X^{2 / 3}}{U}=1.6 \frac{29.91^{1 / 3} 200^{2 / 3}}{6}=28.31 \mathrm{~m}
$$

For momentum effects, $\mathrm{X}>\mathrm{XTEST}$ yielding

$$
\Delta h_{m}=3 * D H M O M=3 * 10.28=30.80 \mathrm{~m}
$$

$$
h(x)=20.0-0.00+28.31+30.84=79.11 \mathrm{~m}
$$

For $\mathrm{D}$ stability $200 \mathrm{~m}$ downwind of release location

$$
\begin{aligned}
& \sigma_{\mathrm{y}}=\frac{\sigma_{\theta} \mathrm{x}}{1+0.031(\mathrm{x})^{0.46}} \quad \sigma_{\mathrm{z}}=0.06 \mathrm{x}(1+0.0015 \mathrm{x})^{-0.5} \\
& \sigma_{\mathrm{y}}=\frac{0.218 * 200 \mathrm{~m}}{1+0.031(200)^{0.46}} \quad \sigma_{\mathrm{z}}=0.06 * 200 \mathrm{~m}(1+0.0015 * 200)^{-0.5} \\
& \sigma_{\mathrm{y}}=32.21 \mathrm{~m} \quad \sigma_{\mathrm{z}}=10.52 \mathrm{~m} \\
& \frac{\chi}{Q}=\frac{e^{-0.5(79.11 / 10.52)^{2}}+\mathrm{e}^{-0.5(79.11 / 10.52)^{2}}}{2^{*} 3.14^{*} 32.21 \mathrm{~m}^{*} 10.52 \mathrm{~m}^{*} 6 \mathrm{~m} / \mathrm{s}}=8.22 \mathrm{E}-17 \mathrm{~s} / \mathrm{m}^{3}
\end{aligned}
$$


The following hand calculation is for a downwind distance of $\mathrm{X}=1000 \mathrm{~m}$.

Since X>XSTR the same equation is used as above except X is replaced with the value of XSTR.

$$
\begin{aligned}
& \Delta h_{B}=1.6 \frac{F_{0}^{1 / 3} X S T R^{2 / 3}}{U} \\
& \Delta h_{B}=1.6 \frac{29.91^{1 / 3} 409.79^{2 / 3}}{6}=45.67 \mathrm{~m}
\end{aligned}
$$

For momentum effects, $\mathrm{X}>\mathrm{XTEST}$ yièlding

$$
\begin{aligned}
& \Delta h_{m}=3 * D H M O M=3 * 10.28=30.80 \mathrm{~m} \\
& h(x)=20.0-0.00+45.67+30.84=96.47 \mathrm{~m}
\end{aligned}
$$

Using the same equation' as above, the pollutant concentration was calculated to be $4.41 \mathrm{E}-07 \mathrm{~s} / \mathrm{m}^{3}$.

\subsection{Building Wake Effects}

The building wake effects will be verified using the input that was specified in Table 7 of the text.

For a downwind distance of $15 \mathrm{~m}$, the length that the recirculation cavity zone extends from the upwind edge of the building is determined using the following expression:

$\mathrm{L}_{c} \approx 0.9 \mathrm{R}$

where

$R \approx\left(B_{\min }\right)^{0.667}\left(B_{\max }\right)^{0.333}$

where $B_{\min }$ is the smaller of $H$ and $W$ and $B_{\max }$ is the larger.

For the building

$R_{u} \approx(10)^{0.667}(20)^{0.333}$

$\mathrm{R}_{\mathrm{u}} \approx 12.6 \mathrm{~m}$

The total is $18.9 \mathrm{~m}$.
For the penthouse

$\mathrm{R}_{\mathrm{s}} \approx(5)^{0.667}(10)^{0.333}$

$\mathrm{R}_{\mathrm{s}} \approx 6.3 \mathrm{~m}$ 
Next a series of tests must be performed as shown in Section 2.3 to determine the correct characteristic length to use for the remainder of the equations. The variable $\mathrm{X}_{\mathrm{s}}$ is equal to the length from the release point to the nearest edge of the building $(10 \mathrm{~m})$.

The conditions for this problem fell into the second set of criteria which are shown as follows.

(ii) $0.5\left(\mathrm{R}_{\mathrm{u}}+\mathrm{R}_{\mathrm{S}}\right)<\mathrm{X}_{\mathrm{S}}<2\left(\mathrm{R}_{\mathrm{u}}+\mathrm{R}_{\mathrm{S}}\right)$.

$0.5(18.9)<10<2(18.9)$ is true therefore the recirculation cavity height $\mathrm{H}_{\mathrm{c}}$ and location $\mathrm{X}_{\mathrm{c}}$ on the upwind portion of the roof are calculated using $R=R_{u}+R_{s}$. The top of this cavity region is joined in a straight line with the top of the penthouse to form a high turbulence zone. The cavity height on the Penthouse roof and the downwind high turbulence zone boundary are then calculated using $R_{\mathrm{S}}$ as a scale length.

Since the position that has been chosen is on the upwind portion of the penthouse, $R_{\text {total }}$ will be used to determine the cavity height and length as follows:

$\mathrm{H}_{\mathrm{c}}=0.22 \mathrm{R}_{\text {total }}$

$\mathrm{H}_{\mathrm{c}}=0.22 * 18.86 \mathrm{~m}$

$\mathrm{H}_{\mathrm{c}}=4.15 \mathrm{~m}$
$\mathrm{X}_{\mathrm{c}}=0.5 \mathrm{R}_{\text {total }}$

$\mathrm{X}_{\mathrm{c}}=0.5 * 18.86 \mathrm{~m}$

$\mathrm{X}_{\mathrm{c}}=9.43 \mathrm{~m}$

The empirical formula for the length of the wake cavity is:

$\mathrm{X}_{\mathrm{r}}=\frac{\mathrm{A}^{*} \mathrm{~W}}{1+\mathrm{B}(\mathrm{W} / \mathrm{H})}$

Two separate combinations of values for $A$ and $B$ are used depending on whether the flow reattaches to the roof and sides of the building. Cases of reattachment occur when the roof cavity length $\left(\mathrm{L}_{\mathrm{c}}\right)$ is less than the length of the building.

Test to see if $0.9 R_{\text {total }}<X_{c}$

$0.9 * 18.86<20$ is true.

For this case $A=1.75$ and $B=0.25$.

Using

$\mathrm{X}_{\mathrm{r}}=\frac{1.75 * 20 \mathrm{~m}}{1+0.25(20 / 10)}$ 
$\mathrm{X}_{\mathrm{r}}=23.33 \mathrm{~m}$

Since $\mathrm{X}_{8}<0.5 \mathrm{R}$

$\mathrm{Z}=0.28 * \mathrm{R} *\left[\frac{\mathrm{X}}{\mathrm{R}}\right]^{0.333}$

$\mathrm{Z}=0.28 * 18.86 \mathrm{~m} *\left[\frac{5}{18.86}\right]^{0.333}$

$\mathrm{Z}=3.39 \mathrm{~m}$

$\mathrm{Z}_{\mathrm{tot}}=\mathrm{Z}+\mathrm{BHT}=3.39 \mathrm{~m}+10 \mathrm{~m}=13.39 \mathrm{~m}$

Now to determine the relative air concentration.

$$
\frac{\chi}{Q}:=\frac{1}{2 \pi \sigma_{y} \sigma_{z} U_{S}}\left[e^{-\left(\frac{\left(z-h_{s}\right)^{2}}{2 \sigma_{s}^{2}}\right)}+e^{-\left(\frac{\left(z+h_{s}\right)^{2}}{2 \sigma_{s}^{2}}\right)}\right]
$$

For $\mathrm{D}$ stability $15 \mathrm{~m}$ downwind of release location

$$
\begin{aligned}
& \sigma_{\mathrm{y}}=\frac{\sigma_{\theta} \mathrm{x}}{1+0.031(\mathrm{x})^{0.46}} \quad \sigma_{\mathrm{z}}=0.06 \mathrm{x}(1+0.0015 \mathrm{x})^{-0.5} \\
& \sigma_{\mathrm{y}}=\frac{0.218 * 15 \mathrm{~m}}{1+0.031(15)^{0.46}} \quad \sigma_{\mathrm{z}}=0.06 * 15 \mathrm{~m}(1+0.0015 * 15)^{-0.5} \\
& \sigma_{\mathrm{y}}=2.954 \mathrm{~m} \quad \sigma_{\mathrm{z}}=0.890 \mathrm{~m} \\
& \frac{\chi}{\mathrm{Q}}=\frac{\mathrm{e}^{-0.5((13.4-20) / 0.89)^{2}}+\mathrm{e}^{-0.5((13.4+20) / 0.89)^{2}}}{2^{*} 3.14^{*} 2.954 \mathrm{~m}^{*} 0.890 \mathrm{~m}^{*} 6 \mathrm{~m} / \mathrm{s}}=1.13 \mathrm{E}-14 \mathrm{~s} / \mathrm{m}^{3}
\end{aligned}
$$

At the remaining distances the calculations are performed in a similar manner. Different equations may be used due to various tests and checks that are performed.

\subsection{Building Wake Effects and Plume Rise Verification}

A simple building was analyzed along with the effects of plume rise for this hand calculation. For input see Table 9 of text. The calculations for several of the parameters are not shown. The user can refer to the first section of this appendix for sample calculations of these parameters. Determination of all other parameters follows: 
Downwind Distance of $30 \mathrm{~m}$.

Plume Rise

Since Fo $\leq 55$ and $X \leq X S T R$ the increase in plume height is equal to the following:

$$
\Delta h_{B}=1.6 \frac{F_{0}^{1 / 3} X^{2 / 3}}{U}=1.6 \frac{31.33^{1 / 3} 30^{2 / 3}}{4}=12.17 \mathrm{~m}
$$

For plume rise due to momentum,

$$
X T E S T=\frac{27.0 * D H M O M}{B 1}=\frac{27.0 * 15.4}{10.4}=39.88 \mathrm{~m}
$$

Since $\mathrm{X}$ is less than XTEST

$$
\Delta h_{m}=\left(B 1 * X * D H M O M^{2}\right)^{1 / 3}=\left(10.4 * 30 * 15.40^{2}\right)^{1 / 3}=42.02 m
$$

For a ground level release with no downwash

$\Delta h=42.02+12.17=54.19 m$

Building Effects

Test to see if $0.9 R_{\text {total }}<X_{c}$

$0.9 * 12.6<30$ is true.

For this case $\mathrm{A}=1.75$ and $\mathrm{B}=\mathbf{0 . 2 5}$.

Using

$$
\begin{aligned}
& \mathrm{X}_{\mathrm{r}}=\frac{1.75 * 20 \mathrm{~m}}{1+0.25(20 / 10)} \\
& \mathrm{X}_{\mathrm{r}}=23.33 \mathrm{~m}
\end{aligned}
$$

For downwind distances less than the length of the building:

$$
\begin{aligned}
& Z=0.27 R-0.1 X \\
& Z=0.27 * 12.6-0.1 * 20=1.4 \mathrm{~m} \\
& \mathrm{Z}_{\text {tot }}=\mathrm{Z}+\mathrm{BHT}=10.0+1.4=11.4 \mathrm{~m}
\end{aligned}
$$


The relative air concentration is determined using the following equation:

$$
\frac{\chi}{Q}=\frac{1}{2 \pi \sigma_{y} \sigma_{z} U_{S}}\left[e^{-\left(\frac{\left(z-h_{s}\right)^{2}}{2 \sigma_{z}^{2}}\right)}+e^{-\left(\frac{\left(z+h_{s}\right)^{2}}{2 \sigma_{z}^{2}}\right)}\right]
$$

For C stability $30 \mathrm{~m}$ downwind of release location

$$
\begin{aligned}
& \sigma_{\mathrm{y}}=\frac{\sigma_{\theta} \mathrm{x}}{1+0.031(\mathrm{x})^{0.46}} \quad \sigma_{\mathrm{z}}=0.06 \mathrm{x}(1+0.0002 \mathrm{x})^{-0.5} \\
& \sigma_{\mathrm{y}}=\frac{0.305 * 30 \mathrm{~m}}{1+0.031(30)^{0.46}} \quad \sigma_{\mathrm{z}}=0.08 * 30 \mathrm{~m}(1+0.0002 * 30)^{-0.5} \\
& \sigma_{\mathrm{y}}=7.98 \mathrm{~m} \quad \cdot \quad \sigma_{\mathrm{z}}=2.39 \mathrm{~m}
\end{aligned}
$$

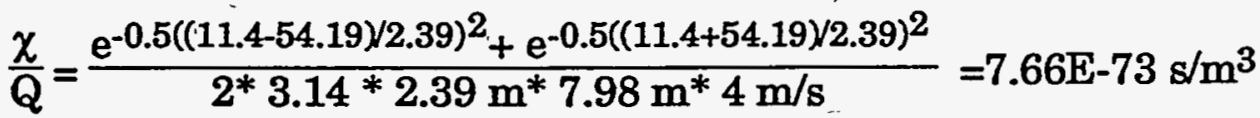

For a downwind distance of $45 \mathrm{~m}$ which is just beyond the building, the calculations are shown below.

For plume rise due to buoyancy with Fo $\leq 55$ and $X<X S T R$, the increase in height is

$$
\Delta \mathrm{h}_{\mathrm{B}}=16 \frac{\mathrm{F}_{0}^{1 / 3} \mathrm{X}^{2 / 3}}{\mathrm{U}}=16 \frac{31.31^{1 / 3} 45^{2 / 3}}{4}=15.95 \mathrm{~m}
$$

Since $\mathrm{X}>\mathrm{XTEST}$

$$
\begin{aligned}
& \Delta h_{m}=3 \times D H M O M=3 \times 15.4=46.2 \mathrm{~m} \\
& \Delta h=15.95 \mathrm{~m}+46.2 \mathrm{~m}=62.15 \mathrm{~m}
\end{aligned}
$$

Building Wake Effects

Since the point $\mathrm{X}$ is beyond the building, $\mathrm{Z}=0$.

Now to determine the relative air concentration 


$$
\frac{\chi}{Q}=\frac{1}{2 \pi \sigma_{y} \sigma_{z} U_{S}}\left[e^{-\left(\frac{\left(z-h_{e}\right)^{2}}{2 \sigma_{z}^{2}}\right)}+e^{-\left(\frac{\left(z+h_{z}\right)^{2}}{2 \sigma_{z}^{2}}\right)}\right]
$$

For C stability $45 \mathrm{~m}$ downwind of release location

$$
\begin{aligned}
& \sigma_{\mathrm{y}}=\frac{\sigma_{\theta} \mathrm{x}}{1+0.031(\mathrm{x})^{0.46}} \quad \sigma_{\mathrm{z}}=0.06 \mathrm{x}(1+0.0002 \mathrm{x})^{-0.5} \\
& \sigma_{\mathrm{y}}=\frac{0.305 * 45 \mathrm{~m}}{1+0.031(45)^{0.46}} \quad \sigma_{\mathrm{z}}=0.08 * 45 \mathrm{~m}(1+0.0002 * 45)^{-0.5} \\
& \sigma_{\mathrm{y}}=11.66 \mathrm{~m} \quad \sigma_{\mathrm{z}}=3.58 \mathrm{~m} \\
& \frac{\chi}{Q}=\frac{\mathrm{e}^{-0.5((62.15) / 3.58)^{2}}+\mathrm{e}^{-0.5((62.15) / 3.58)^{2}}}{2^{*} 3.14^{*} 3.58 \mathrm{~m}^{*} 11.66 \mathrm{~m}^{*} 4 \mathrm{~m} / \mathrm{s}}=9.51 \mathrm{E}-69 \mathrm{~s} / \mathrm{m}^{3}
\end{aligned}
$$

For a downwind distance of $100 \mathrm{~m}$.

For plume rise due to buoyancy and since Fo $\leq 55$ and $X<X S T R$ the increase in plume height is

$$
\Delta \mathrm{h}_{\mathrm{B}}=1.6 \frac{\mathrm{F}_{\mathrm{o}}^{1 / 3} \mathrm{X}^{2 / 3}}{\mathrm{U}}=1.6 \frac{31.31^{1 / 3} 100^{2 / 3}}{4}=27.16 \mathrm{~m}
$$

Since $\mathrm{X}>\mathrm{XTEST}$

$$
\Delta \mathrm{h}_{\mathrm{m}}=3 \times \mathrm{DHMOM}=3 \times 15.4=46.2 \mathrm{~m}
$$

$\Delta \mathrm{h}=27.16 \mathrm{~m}+46.2 \mathrm{~m}=73.36 \mathrm{~m}$

Building Wake Effects

Since the point $\mathrm{X}$ is beyond the building, $\mathrm{Z}=0$.

Now to determine the relative air concentration

$$
\frac{\chi}{Q}=\frac{1}{2 \pi \sigma_{y} \sigma_{z} U_{S}}\left[e^{-\left(\frac{\left(z-h_{s}\right)^{2}}{2 \sigma_{z}^{2}}\right)}+e^{-\left(\frac{\left(z+h_{f}\right)^{2}}{2 \sigma_{z}^{2}}\right)}\right]
$$


For C stability $100 \mathrm{~m}$ downwind of release location

$$
\begin{aligned}
& \sigma_{\mathrm{y}}=\frac{\sigma_{\theta \mathrm{x}}}{1+0,031(\mathrm{x})^{0.46}} \\
& \sigma_{\mathrm{z}}=0.06 \mathrm{x}(1+0.0002 \mathrm{x})^{-0.5} \\
& \sigma_{\mathrm{y}}=\frac{0.305 * 100 \mathrm{~m}}{1+0.031(100)^{0.46}} \\
& \sigma_{\mathrm{z}}=0.08 * 100 \mathrm{~m}(1+0.0002 * 100)^{-0.5} \\
& \sigma_{\mathrm{y}}=24.28 \mathrm{~m} \\
& \sigma_{\mathrm{z}}=7.92 \mathrm{~m} \\
& \frac{\chi}{Q}=\frac{e^{-0.5((73.36) / 7.92)^{2}+\mathrm{e}^{-0.5((73.36) / 7.92)^{2}}}}{2^{*} 3.14 * 7.92 \mathrm{~m}^{*} 24.28 \mathrm{~m}^{*} 4 \mathrm{~m} / \mathrm{s}}=9.70 \mathrm{E}-23 \mathrm{~s} / \mathrm{m}^{3}
\end{aligned}
$$

For a downwind distance of $500 \mathrm{~m}$.

For plume rise due to buoyancy, using the parameters shown in Figure A2 and since Fo $\leq 55$ and $X \geq X S T R$

$$
\Delta \mathrm{h}_{\mathrm{B}}=1.6 \frac{\mathrm{F}_{\mathrm{o}}^{1 / 3} \mathrm{XSTR}^{2 / 3}}{\mathrm{U}}=16 \frac{31.31^{1 / 3} 421.69^{2 / 3}}{4}=70.90 \mathrm{~m}
$$

Since $X>X T E S T$

$$
\begin{aligned}
& \Delta h_{m}=3 \times D H M O M=3 \times 15.4=46.19 m \\
& \Delta h=70.90 m+46.19 m=117.09 m
\end{aligned}
$$

Building Wake Effects

Since the point $\mathrm{X}$ is beyond the building, $\mathrm{Z}=0$.

Now to determine the relative air concentration

$$
\frac{\chi}{Q}=\frac{1}{2 \pi \sigma_{y} \sigma_{z} U_{S}}\left[e^{-\left(\frac{\left(z-h_{s}\right)^{2}}{2 \sigma_{z}^{2}}\right)}+e^{-\left(\frac{\left(z+h_{c}\right)^{2}}{2 \sigma_{s}^{2}}\right)}\right]
$$


For $\mathrm{C}$ stability $500 \mathrm{~m}$ downwind of release location

$$
\begin{aligned}
& \sigma_{y}=\frac{\sigma_{\theta x}}{1+0.031(x)^{0.46}} \quad \sigma_{z}=0.06 x(1+0.0002 x)^{-0.5} \\
& \sigma_{\mathrm{y}}=\frac{0.305 * 500 \mathrm{~m}}{1+0.031(500)^{0.46}} \quad \sigma_{\mathrm{z}}=0.08 * 500 \mathrm{~m}(1+0.0002 * 500)^{-0.5} \\
& \sigma_{\mathrm{y}}=99.13 \mathrm{~m} \quad \sigma_{\mathrm{z}}=38.13 \mathrm{~m} \\
& \frac{\chi}{Q}=\frac{\mathrm{e}^{-0.5((117.09) / 38.13)^{2}}+\mathrm{e}^{-0.5((117.09) / 38.13)^{2}}}{2^{*} 3.14^{*} 99.13 \mathrm{~m}^{*} 38.13 \mathrm{~m}^{*} 4 \mathrm{~m} / \mathrm{s}}=1.88 \mathrm{E}-07 \mathrm{~s} / \mathrm{m}^{3}
\end{aligned}
$$

